\title{
Real-time Direct Detection of Silica Scaling on RO Membranes
}

\author{
John Thompson $^{(\mathrm{a})}$, Anditya Rahardianto ${ }^{(\mathrm{a})}$, Soomin Kim ${ }^{(\mathrm{a})}$, Muhammad Bilal $^{(\mathrm{a})}$, \\ Richard Breckenridge $^{(\mathrm{b})}$, and Yoram Cohen ${ }^{(\mathrm{a}), 1}$ \\ (a) Chemical and Biomolecular Engineering Department \\ and \\ Water Technology Research (WaTeR) Center \\ University of California, Los Angeles \\ Los Angeles, California USA 90095-1592 \\ (b) Electric Power Research Institute \\ 3420 Hillview Avenue, Palo Alto, CA 94304
}

Submitted: October 11, 2016

Received for revision: November 18, 2016

Revised: December 29, 2016

Journal of Membrane Science

1 Corresponding author. Email: yoram@ucla.edu; Phone: (310) 825-8766 


\begin{abstract}
Silica scaling of RO membranes was evaluated via real-time direct surface imaging demonstrating a capability for detecting the onset of silica scale formation and its evolution. Silica scaling was detected significantly earlier than by traditional flux decline measurements. The observed rate of silica particle nucleation followed classical nucleation theory while the growth of individual silica particles, at the early stages of silica scaling, was governed by diffusional growth. SEM and optical images of the membrane surface suggest that silica scaling occurs through the formation of both primary silica particles and their agglomerates $(\sim 1-30 \mu \mathrm{m})$, as well as a gel-like silica film embedded with silica particles both of which contribute to permeate flux decline. At low silica saturation index at the membrane surface $\left(\mathrm{SI}_{\mathrm{m}} \leq 1.93\right)$ silica gel film formation resulted in a smoother and less porous film than at higher silica saturation $\left(\mathrm{SI}_{\mathrm{m}} \geq 2.72\right)$. At the higher silica saturation levels $\left(\mathrm{SI}_{\mathrm{m}}=2.72-3.50\right)$, silica scaling resulted in larger observed particles as well as rapid permeate flux decline. The silica scale layer thickness was in the range of $\sim 0.1-3.5 \mu \mathrm{m}$, with surface roughness being higher by a factor of $2.6-8.3$ relative to the native membrane. Results of the present study suggest that there is merit in exploring the application of the present approach for early detection and monitoring of silica scaling in RO plants in support of strategies for silica scale mitigation.
\end{abstract}

Keywords: direct membrane surface imaging, silica scaling, flux decline, reverse osmosis, scale detection 


\section{Introduction}

Inland water treatment via RO desalination of brackish groundwater and industrial cooling water (blowdown) is often hampered by mineral scaling which limits the attainable product water recovery [1-7]. As water recovery increases, the concentration of sparingly soluble mineral salts increases in the RO feed channel and surpass their solubility limit and precipitate in both the bulk and onto the membrane surface. Typical mineral scalants of concern include calcium sulfate [2, 3, 8-13], calcium carbonate [2, 14], calcium phosphate [15-17], barium sulfate [18], and silica $\left(\mathrm{SiO}_{2}\right)[6,19-27]$. Surface scale formed by such scalants will block the membrane surface, thereby reducing membrane productivity and decreasing membrane longevity both which lead to higher operating costs $[1,9-12,28,29]$.

Silica scaling, which is the focus of the present work, can be particularly problematic, even when hardness is removed from source water $[4,5,13,21,30,31]$. The range of encountered silica concentrations typically in the range of $\sim 12-60 \mathrm{mg} / \mathrm{L}[3,13,22,26,32,33]$ for brackish water and $\sim 50-200 \mathrm{mg} / \mathrm{L}[6,34]$ for certain industrial wastewater streams (e.g., cooling tower blowdown (CTBD) water). Upon RO desalination of such water sources, silica concentration can exceed silica solubility which, for example, is $\sim 115 \mathrm{mg} / \mathrm{L}$ at $\mathrm{pH}=7$ and $25^{\circ} \mathrm{C}[35,36]$. Under saturated conditions, silica in solution can form "polymeric silica" and spherical colloidal particles in the nano-size range that may further agglomerate [21, 22, 37-41] to form particles in the submicron size range.

Silica polymerization initially involves silanol groups reacting to form dimers. In neutral or acidic conditions $(\mathrm{pH}<7.5)$ silicic acid dimerizes according to the condensation reaction $[21,36$, 37, 42, 43]:

$$
2 \mathrm{Si}(\mathrm{OH})_{4} \rightarrow(\mathrm{OH})_{3} \mathrm{SiOSi}(\mathrm{OH})_{3}+\mathrm{H}_{2} \mathrm{O}
$$


and under alkaline conditions $(\mathrm{pH}>7.5)$, silica reportedly dimerizes with silicate ion according to $[37,44]$ :

$$
\mathrm{Si}(\mathrm{OH})_{4}+\mathrm{SiO}(\mathrm{OH})_{3}^{-} \rightarrow(\mathrm{OH})_{3} \mathrm{SiOSi}(\mathrm{OH})_{3}+(\mathrm{OH})^{-}
$$

Silica dimers can then polymerize further with large formed oligomers that grow to larger particles, which can agglomerate into rearrangeable networks or "gel" that makes up amorphous silica scale $[21,37,45,46]$. It is noted that while silica solubility increases with temperature [21, $35,47-49]$, the rate of silica polymerization is higher at elevated $\mathrm{pH}$ and temperature [38-41].

In order to mitigate silica scaling in RO operations, chemical antiscalants are often utilized $[22,46,50-52]$ in addition to operation at high $\mathrm{pH}$ when feasible [21]. In all cases, early detection of silica scaling is desirable in order to trigger the appropriate strategy of mitigating silica scale which can be challenging to remove $[25,51,53,54]$. In this regard, various studies have focused on monitoring flux decline (for constant pressure operation) or transmembrane pressure rise (for constant flux operation) in order to determine the onset and severity of silica scaling $[55,56]$. These approaches, however, are of insufficient accuracy for detecting the onset of scale formation.

Other approaches for monitoring fouling and mineral scaling that have been advanced in recent years include, for example, ultrasonic time-domain reflectometry (UTDR) [57-61] and electrical impedance spectroscopy (EIS) [62-64]. UTDR is used to determine the thickness of the foulant layer (without the ability to identify the foulant itself) and is typically accomplished in a specialized membrane cell [56-59]. Silica scaling studies that have focused on UTDR as the scale monitoring approach have been carried out with feed of $200 \mathrm{mg} / \mathrm{L}$ colloidal silica and reported estimated fouling layer thickness of 11-15 $\mu \mathrm{m}$ [57]. Comparisons of UTDR and flux decline measurements have shown that the approach essentially parallels the level of accuracy obtained with flux decline measurements. In contrast with UTDR, EIS is a method that relies on 
in-situ measurements of changes in the electrical properties of the membrane (e.g., impedance, capacitance, or conductance), due to the presence of a foulant layer [62, 64]. RO studies with silica feed concentration of $200 \mathrm{mg} / \mathrm{L}$ have shown a measurable shift in impedance and conductance signals after 5 hours of operation and prior to significant TMP increase ( $\geq 5 \%)$ [62]. It is noted that both EIS and UTDR only provide an indirect indication of the buildup of a foulant layer. It is also emphasized that in the above studies silica scaling was induced by colloidal silica introduced in the feed solution. This is in contrast to the scenario of silica precipitation (from unsaturated silica feed solution) as a consequence of solution supersaturation resulting from concentration polarization (CP) in the RO channel.

In contrast with the above described indirect scale detection methods, direct visual membrane surface monitoring, under high pressure RO operation, can provide $[10,12,32,65-67]$ an unambiguous detection of onset of mineral scaling and fouling. Moreover, through real-time image analysis, scaling kinetics can be quantified and scale morphology can also be ascertained $[2,8,10,12,32,65,68]$. While the approach pioneered in $[2,8,10,12,32,65,67-69]$ was shown to be effective for detection of calcite, gypsum and biofouling, real-time monitoring of silica scale has not been reported, in part due to the challenge of performing real-time image analysis. Accordingly, the present work focuses on demonstrating early detection of silica scaling (relative to flux decline measurements) on RO membranes and elucidating its kinetics via a novel real-time direct visual membrane surface monitoring approach. The kinetics of silica scaling (in terms of both surface coverage and surface number density of silica particles) were then quantified as a function of the level of silica supersaturation at the membrane surface. In addition, the morphology of silica scale on the membrane surface was characterized at high resolution, via scanning electron microscopy (SEM) and atomic force microscopy (AFM), to 
illustrate the complex nature of silica scaling and demonstrate the presence of silica particles, aggregates, and gel-like silica film coverage.

\section{Experimental}

\subsection{Membrane Monitoring System}

Membrane scaling tests were performed with a novel membrane monitoring system [26] consisting of a transparent high pressure plate-and-frame RO (PFRO) membrane cell (Fig. 1) $[10,12,32,65,66,69,70]$, having flow channel dimensions of $3.1 \mathrm{~cm}$ (width) x $8.8 \mathrm{~cm}$ (length) x $0.25 \mathrm{~cm}$ (height) with an active membrane surface area of $27.4 \mathrm{~cm}^{2}$. Given the small active surface area, the attainable recovery is typically $<1 \%$. The hydrodynamics and mass transfer characteristics of the PFRO membrane cell have been previously described, along with detailed quantification of concentration polarization $[65,69,70]$. Specialized external lighting was arranged along the membrane cell to provide high contrast relative to the native membrane

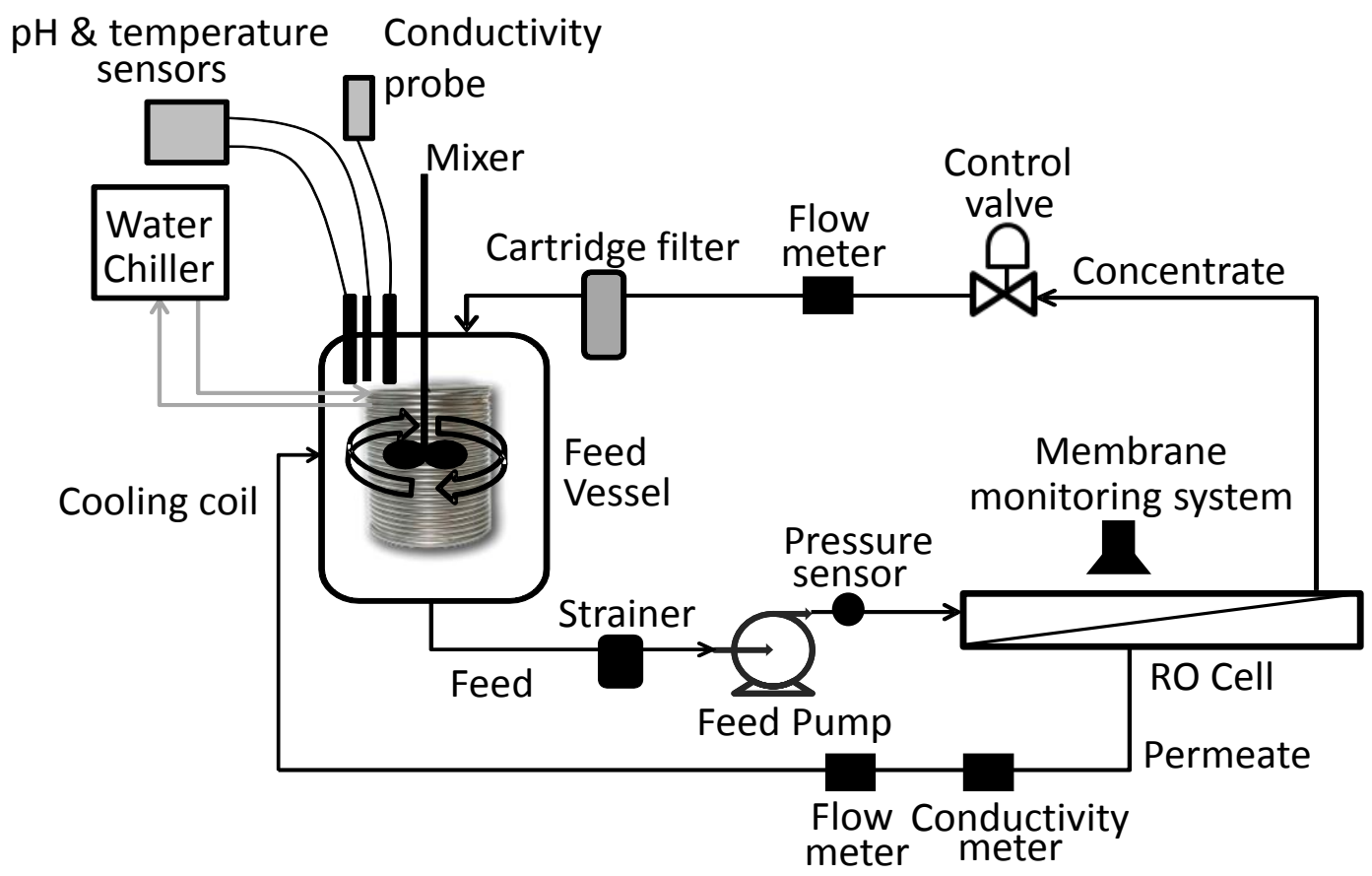

Figure 1. RO membrane monitoring system used in total recycle mode for silica scaling studies. 
background. Real-time surface images were captured with a digital microscope at high resolution (2592 x 1944) and transmitted to a computer for real-time monitoring and analysis.

All silica scaling experiments were carried out in a total recycle mode whereby the RO concentrate and permeate streams were returned to the feed vessel with the feed solution continuously mixed (using Stirrer Type RZR1; Caframo Limited, Georgian Bluffs, Ontario, Canada) (Fig. 1). The feed solution was pumped to the RO monitoring cell from a 25 -liter plastic feed vessel using a 3/4 hp (559 W) positive displacement pump (Hydra-Cell Model P100; Wanner Engineering, Inc., Minneapolis, MN) controlled using a variable-frequency drive (VFD) (VS1MX11-4D Microdrive; Baldor Electric Company, Fort Smith, AR). The feed stream, prior to the pump inlet, was filtered through a 200 mesh $(\sim 75 \mu \mathrm{m})$ polyethylene strainer (Ron-Vik, Inc., Minneapolis, $\mathrm{MN})$. The RO concentrate was filtered using a $0.35 \mu \mathrm{m}$ pleated cartridge filter (Harmsco, Inc., North Palm Beach, FL) prior to returning to the feed vessel. Transmembrane pressure (TMP) was adjusted using the pump VFD and a back-pressure control valve (Jordan LowFlow Model MK708 LMO; LA Valves \& Automation, Inc., Corona, CA) at the concentrate stream exit and monitored using both a digital pressure transducer and a mechanical pressure gauge (Model A-10, Model 232.53, respectively; Wika Instrument LP, Lawrenceville, GA). The feed and permeate volumetric flow rates were monitored using digital flow meters (Feed: Model 2000 Micro Flow, Georg Fischer Signet, El Monte, CA; Permeate: (FlowCal 5000 HPLC Liquid Flow Meter; Tovatech LLC, South Orange, NJ). RO permeate conductivity was monitored using an inline digital conductivity sensor (Model 2850; Georg Fischer Signet, El Monte, CA).

All scaling experiments were performed in a constant TMP mode. The feed solution temperature was maintained at $20 \pm 1^{\circ} \mathrm{C}$ using a recirculation water chiller (Neslab RTE-111; ThermoFisher Scientific, Waltham, MA) connected to a stainless steel cooling coil within the feed vessel. The feed solution electrical conductivity was measured using a conductivity meter 
(Con 110; Oakton Instruments, Vernon Hills, IL). The feed solution $\mathrm{pH}$ and temperature were monitored using a digital $\mathrm{pH}$ meter with built-in temperature sensor (sensION 4; Hach Company, Loveland, CO) and pH probes (PHG211-8 and REF201; Radiometer Analytical SAS, Lyon, France).

\subsection{Materials and Reagents}

A commercial flat-sheet brackish water RO membrane (UTC-70AC; Toray Membrane USA, Poway, CA) was used for all silica scaling experiments. This membrane was selected given its suitability for RO desalination of brackish water. Prior to testing, each membrane coupon was cut from a flat-sheet roll, rinsed for 1-2 minutes and soaked in distilled water (electrical conductivity $\leq 1 \mu \mathrm{S} / \mathrm{cm}$ ) in a covered beaker for $1-2$ hours. The membranes were first conditioned in the RO cell with distilled water for 1 hour. The hydraulic membrane permeability was determined using distilled water to be $6.5 \pm 0.5 \times 10^{-3} \mathrm{~m}^{3} /\left(\mathrm{m}^{2} \cdot \mathrm{hr} \cdot \mathrm{bar}\right)$, over a TMP range of $0.47-$ 2.07 MPa (4.7-20.7 bar). Subsequently, the membrane was conditioned with a $2000 \mathrm{mg} / \mathrm{L} \mathrm{NaCl}$ solution at a steady TMP of 1.38 MPa (13.8 bar) until the permeate flow rate stabilized (typically $\sim 4 \mathrm{hrs}$ ), during which time the observed membrane salt rejection $\left(\mathrm{R}_{\mathrm{o}}\right)$ was also determined to be $98 \pm 0.5 \%$, using electrical conductivity measurements $\left(R_{o}=1-\left(C_{P} / C_{F}\right)\right.$, where $C_{P}$ and $C_{F}$ are the conductivities of the permeate stream and the feed solution, respectively). At the end of each membrane test, the membrane was removed from the PFRO cell, briefly immersed in distilled water to remove residual solution, dried in air, and stored in sealed plastic containers for further analysis.

Silica feed solutions were prepared by dissolving and mixing sodium metasilicate pentahydrate $\left(\mathrm{Na}_{2} \mathrm{SiO}_{3} \cdot 5 \mathrm{H}_{2} \mathrm{O}\right)$ as a silica source $(99 \%$ purity in powder form; Strem Chemicals, Inc., Newburyport, MA) as recommended in previous studies on RO membrane silica scaling 
$[22,51,55,71]$. The feed solution also included sodium chloride $(\mathrm{NaCl})(99 \%$ granular; Fisher Scientific, Pittsburgh, PA), and sodium bicarbonate $\left(\mathrm{NaHCO}_{3}\right)(99 \%$ powder; Fisher Scientific, Pittsburgh, PA) as a $\mathrm{pH}$ buffer. Upon preparation and prior to acidification, the feed solution $\mathrm{pH}$ was $\sim 11$, at which the silica $\left(\mathrm{SiO}_{2}\right)$ concentration is predicted to be well below its solubility limit (Fig. 2).

\subsection{Silica Scaling Experiments}

Prior to each silica scaling run, the PFRO system was cleaned with an aqueous solution of $\mathrm{NaOH}$ (50\% in $\mathrm{H}_{2} \mathrm{O}$; Sigma-Aldrich Corporation, St. Louis, $\mathrm{MO}$ ) diluted in distilled water to a $\mathrm{pH}$ of $\sim 12$. The cleaning solution was pumped through the PFRO system in recycle mode for 2 hours to dissolve residual silica. The cleaning solution was then purged and the PFRO feed vessel was rinsed with distilled water that was circulated through the system for at least 1 hour. The process of refilling the feed vessel with distilled water, circulation, and draining was repeated at least twice, and until the feed vessel solution reached a $\mathrm{pH} \leq 7$. The feed vessel was then drained and filled with the silica feed solution for the next silica scaling test.

The feed solution contained $360 \mathrm{mg} / \mathrm{L} \mathrm{Na} \mathrm{SiO}_{3} \cdot 5 \mathrm{H}_{2} \mathrm{O}, 85 \mathrm{mg} / \mathrm{L} \mathrm{NaHCO}$, and $2000 \mathrm{mg} / \mathrm{L}$ $\mathrm{NaCl}$ (Table 1). However, for the two experiments at the lowest $\mathrm{SI}_{\mathrm{m}}$ (i.e., 1.60 and 1.93, Table 2) $\mathrm{NaCl}$ concentration in the feed was raised to $4,000 \mathrm{mg} / \mathrm{L}$ in order to increase the feed osmotic pressure and thus avoid operating at low TMP levels for the required initial permeate flux $(<0.34$ MPa (3.4 bar)) which would have resulted in feed pump pressure oscillations. It is noted that although salinity may decrease silica solubility [21, 37, 43, 72-75], over the range of 2,000-4,000 $\mathrm{mg} / \mathrm{L} \mathrm{NaCl}$ there was less than $1 \%$ change in silica saturation index (SI). The feed solution was acidified, while mixing, by gradually adding concentrated $\mathrm{HCl}$ into the feed vessel to reach an initial $\mathrm{pH}$ of 6.0 prior to the start of each experimental run. The above $\mathrm{pH}$ level was set in order 
to minimize changes in solubility due to $\mathrm{pH}$ fluctuation and maintain the $\mathrm{pH}<8$, (i.e., since silica solubility increases rapidly at $\mathrm{pH}>8$ ). The saturation index of silica was calculated as $S I_{\mathrm{SiO}_{2}(s)}=a_{\mathrm{SiO}_{2}(a q)} / K_{s p, \mathrm{SiO}_{2}(s)}$, in which $K_{s p}$ is the solubility constant, and where $a_{\mathrm{SiO}_{2} \text { (aq) }}=\gamma_{\mathrm{SiO}_{2} \text { (aq) }} \cdot x_{\mathrm{SiO}_{2} \text { (aq) }}$ is the activity of $\mathrm{SiO}_{2}$ in the aqueous phase with $\gamma_{\mathrm{SiO}_{2} \text { (aq) }}$ and $x_{\mathrm{SiO}_{2} \text { (aq) }}$ being the activity coefficient and mole fraction of silica, respectively. The calculations of $\mathrm{SI}_{\mathrm{SiO}_{2}(s)}$ were performed using the OLI thermodynamic multi-electrolyte package [76] for the present experimental conditions (Tables 1 and 2).

Table 1. Silica feed solution.

\begin{tabular}{|c|c|}
\hline Analyte & Concentration $(\mathrm{mg} / \mathrm{L})$ \\
\hline \multicolumn{2}{|l|}{ Feed constituents } \\
\hline $\mathrm{Na}_{2} \mathrm{SiO}_{3} \cdot 5 \mathrm{H}_{2} \mathrm{O}$ & 360 \\
\hline $\mathrm{NaHCO}_{3}$ & 85 \\
\hline $\mathrm{NaCl}$ & $2000-4000$ \\
\hline $\mathrm{SiO}_{2}^{(\mathrm{a})}$ & 102 \\
\hline $\mathrm{SiO}_{2}$ solubility ${ }^{(\mathrm{a})}$ & 104 \\
\hline Silica $\left(\mathrm{SiO}_{2}\right)$ bulk saturation index ${ }^{(\mathrm{a})}$ & 0.987 \\
\hline $\mathrm{pH}^{(\mathrm{a})}$ & 6.0 \\
\hline Temperature $\left({ }^{\circ} \mathrm{C}\right)^{(\mathrm{a})}$ & 20 \\
\hline
\end{tabular}

Table 2. Experimental conditions for silica scaling tests ${ }^{(a)}$.

\begin{tabular}{cccccc}
\hline $\begin{array}{c}\text { Test } \\
\text { No. }\end{array}$ & $\begin{array}{c}\text { Initial } \\
\text { Permeate } \\
\text { Flux } \\
\left(\mathbf{L} / \mathbf{m}^{2} \text {-hr }\right)\end{array}$ & $\begin{array}{c}\text { Initial } \\
\text { Average } \\
\text { CP }\end{array}$ & $\begin{array}{c}\mathbf{S I}_{\mathbf{m}} \text { at the monitored } \\
\text { region and average } \\
\text { value }\left(\overline{\mathrm{SI}}_{\mathrm{m}}\right)\end{array}$ & $\begin{array}{c}\text { Initial Local } \\
\text { (and Average) } \\
\text { Surface SiO } \\
\text { Conc. }(\mathbf{m g} / \mathbf{L})\end{array}$ & $\begin{array}{c}\text { Equivalent } \\
\text { Recovery } \\
\text { (average) }(\%)\end{array}$ \\
\hline 1 & 16.6 & 1.60 & $1.60(1.58)$ & $165(163)$ & 36.7 \\
2 & 24.1 & 1.80 & $1.93(1.79)$ & $199(184)$ & 44.1 \\
3 & 28.5 & 1.95 & $2.10(1.94)$ & $220(199)$ & 48.4 \\
4 & 43.4 & 2.45 & $2.72(2.39)$ & $281(244)$ & 58.1 \\
5 & 63.5 & 3.10 & $3.50(3.10)$ & $361(316)$ & 67.7
\end{tabular}

(a) Crossflow velocity for each test was maintained at $4.2 \mathrm{~cm} / \mathrm{s}$ for which $\mathrm{Re}=107$; the Reynolds number is defined as $\mathrm{Re}=\mathrm{u} \cdot \mathrm{H} / \mathrm{v}$, where $\mathrm{u}$ is the average crossflow velocity, $\mathrm{H}$ is the channel height, and $v$ is the solution kinematic viscosity at $20^{\circ} \mathrm{C} ; \mathrm{SI}_{\mathrm{m}}$ and $\overline{\mathrm{SI}}_{\mathrm{m}}$ are the silica saturation indices at the membrane surface in the monitored region and the axially average value along the membrane surface. 


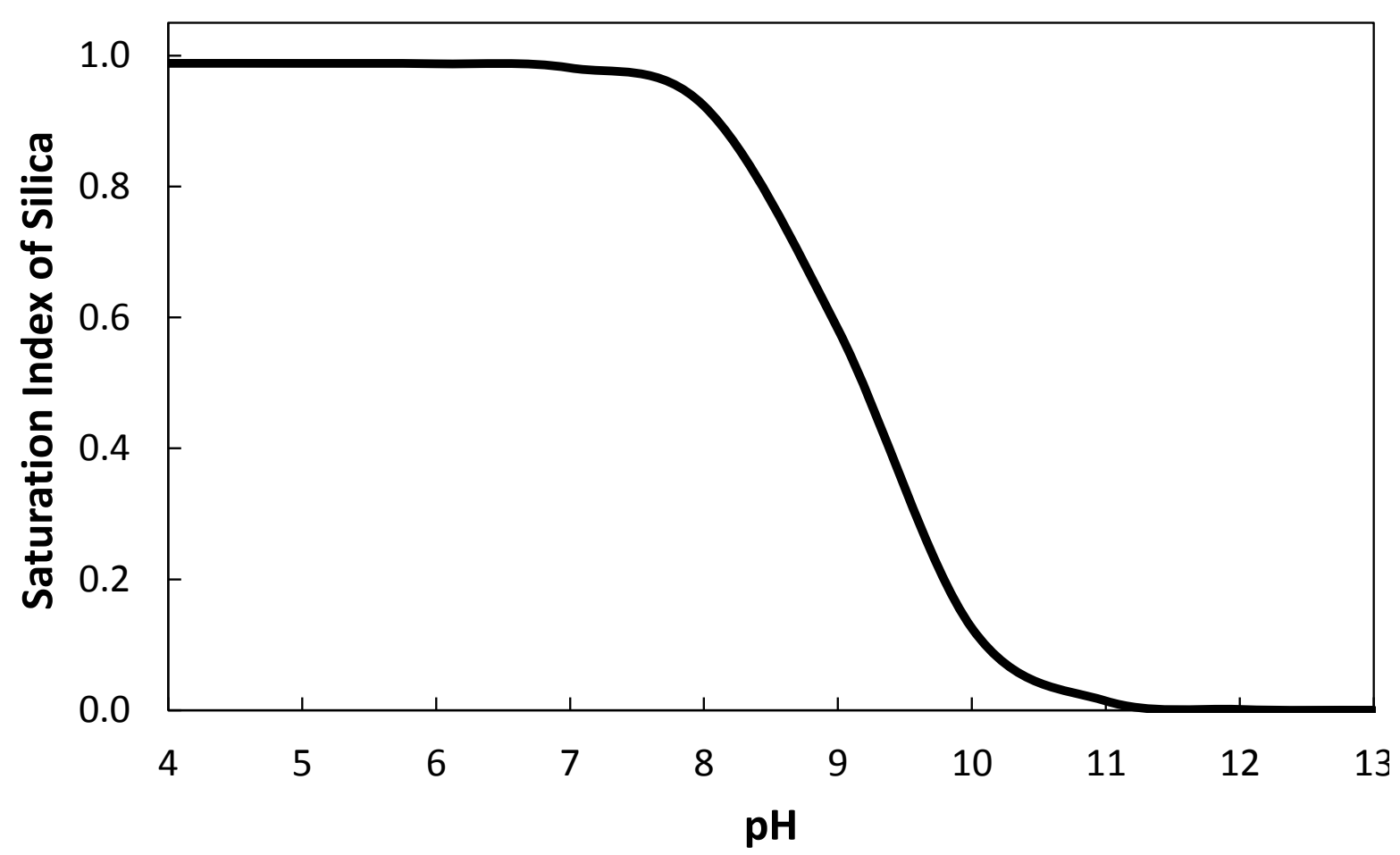

Figure 2. Effect of $\mathrm{pH}$ on silica saturation index for the $\mathrm{RO}$ feed solution used in the present study $\left(\mathrm{T}=20^{\circ} \mathrm{C}\right)$, total silica concentration $=1.7 \mathrm{mM}\left(102 \mathrm{mg} / \mathrm{L} \mathrm{SiO}_{2}\right)$.

At $\mathrm{pH}=6.0$, the feed was nearly saturated with respect to silica (Section 2.2, Fig. 2), with SI $\sim 99\left(\mathrm{~T}=20^{\circ} \mathrm{C}\right)$. During each run, the $\mathrm{pH}$ gradually increased from its initial $\mathrm{pH} \sim 6.0$ to a stable $\mathrm{pH}$ value of $7.2 \pm 0.2$; the above behavior was expected due to carbon dioxide degassing until equilibrium was reached with respect to the bicarbonate in solution. Over the above range of $\mathrm{pH}$ increase, the bulk SI decreased by $<1 \%$ (i.e., from 0.987 to 0.981 ). At the above experimental conditions, the condition of SI $<1$ (Table 1) was maintained such that silica precipitation did not occur in the feed solution. Given the above solution composition, it was not anticipated that any form of fouling other than by silica could take place.

The feed crossflow velocity in the RO channel was maintained the same $(4.2 \mathrm{~cm} / \mathrm{s})$ for all scaling tests. Therefore, in order to achieve the desired level of silica supersaturation at the membrane surface, the transmembrane pressure was set so as to control the permeate flux and 
thus the $\mathrm{CP}$ level at the membrane surface $[69,70,77]$. The $\mathrm{CP}$ level (defined as $\mathrm{CP}=\mathrm{C}_{\mathrm{m}} / \mathrm{C}_{\mathrm{b}}$, where $C_{m}$ and $C_{b}$ are the silica concentrations at the membrane surface and in the bulk solution, respectively) was determined (Table 2) at the location of the membrane surface monitored region and average value over the channel length given the detailed CFD characterization available for the present PFRO cell $[69,70]$. For the range of present experimental conditions, the resulting initial $\mathrm{SI}_{\mathrm{m}}$ at the membrane surface (in the monitored region) was in the range of 1.60-3.50 (with channel average values in the range of $\overline{\mathrm{SI}}_{\mathrm{m}}=1.58-3.10$ ). It can be shown, following the approach described in [3], that the SI range (Table 2) above, with the current silica feed solution (102 mg/L silica), would be expected in a spiral-wound RO plant operating at a recovery of $36.7-67.7 \%$. It is noted that silica concentration in brackish groundwater is typically reported in the range of $\sim 12-60 \mathrm{mg} / \mathrm{L}[3,13,22,26,32,33]$ for which the present range of $\mathrm{SI}_{\mathrm{m}}$ would be reached at recovery levels of $\sim 62-95 \%$. Therefore, it can be stated that the present experimental approach does cover the range of $\mathrm{SI}_{\mathrm{m}}$ that would be expected under a reasonable range of practical high recovery RO field operations.

\subsection{Membrane Surface Scale Analysis}

\subsubsection{Real-time Membrane Image Analysis}

The monitored membrane area (field of view of $\sim 36.2 \mathrm{~mm}^{2}$ ) was located between the center and downstream sections of the membrane channel (total membrane area: $27.4 \mathrm{~cm}^{2}$ ), centered at $6.1 \mathrm{~cm}$ from the channel inlet. Image analysis of the membrane surface images was conducted using the software described in [66], with incorporation of adaptive image segmentation to highlight and quantify persistent surface changes due to mineral scaling or fouling [78]. Images were first converted to grayscale and subsequently aligned to enable accurate image comparison. Image subtraction was then carried out by subtracting the initial image at $t=0$ (regarded as 
clean) from each subsequent image, in order to identify the evolution of surface changes over time (Fig. 3). The resulting image was enhanced based on histogram equalization in order to account for undesired lighting effects (e.g., shadows) and background noise [79, 80] and the resulting subtracted image was segmented (i.e., thresholded) to yield the final processed binary image. The current analysis approach enabled detection of surface objects (particles) of size encompassing 50 pixels $\left(\sim 0.35 \mu \mathrm{m}^{2}\right)$ and larger. The identified scaled areas were quantified with respect to the scale surface area coverage, and the identified scaled entities (i.e., particles) were enumerated to track the temporal evolution of the particles SND and the fractional coverage in the field of view.

\subsubsection{SEM-EDS Analysis of Membrane Samples}

Membrane samples were analyzed using scanning electron microscopy (JSM-6700F Field Emission SEM; JEOL, Ltd., Tokyo, Japan) and EDS (EDAX Genesis Spectrum; EDAX Inc., Mahwah, NJ). Prior to analysis, membrane samples were pre-coated using a vacuum sputtering system with a 15-20 nm layer of gold in order to increase the electrical conductivity of the samples (Hummer 6.2 Sputtering System; Anatech USA, Union City, CA). EDS enabled determination of the major elements present in the membrane foulant layer. Samples were also sectioned and imaged via Focused Ion Beam (FIB) SEM (Nova 600 NanoLab DualBeam

SEM/FIB; FEI Company, Hillsboro, OR). These samples were first coated with 50-60 nm of gold and a thin strip of platinum was coated on the sample above the cross-sectioned location just prior to FIB sectioning. 


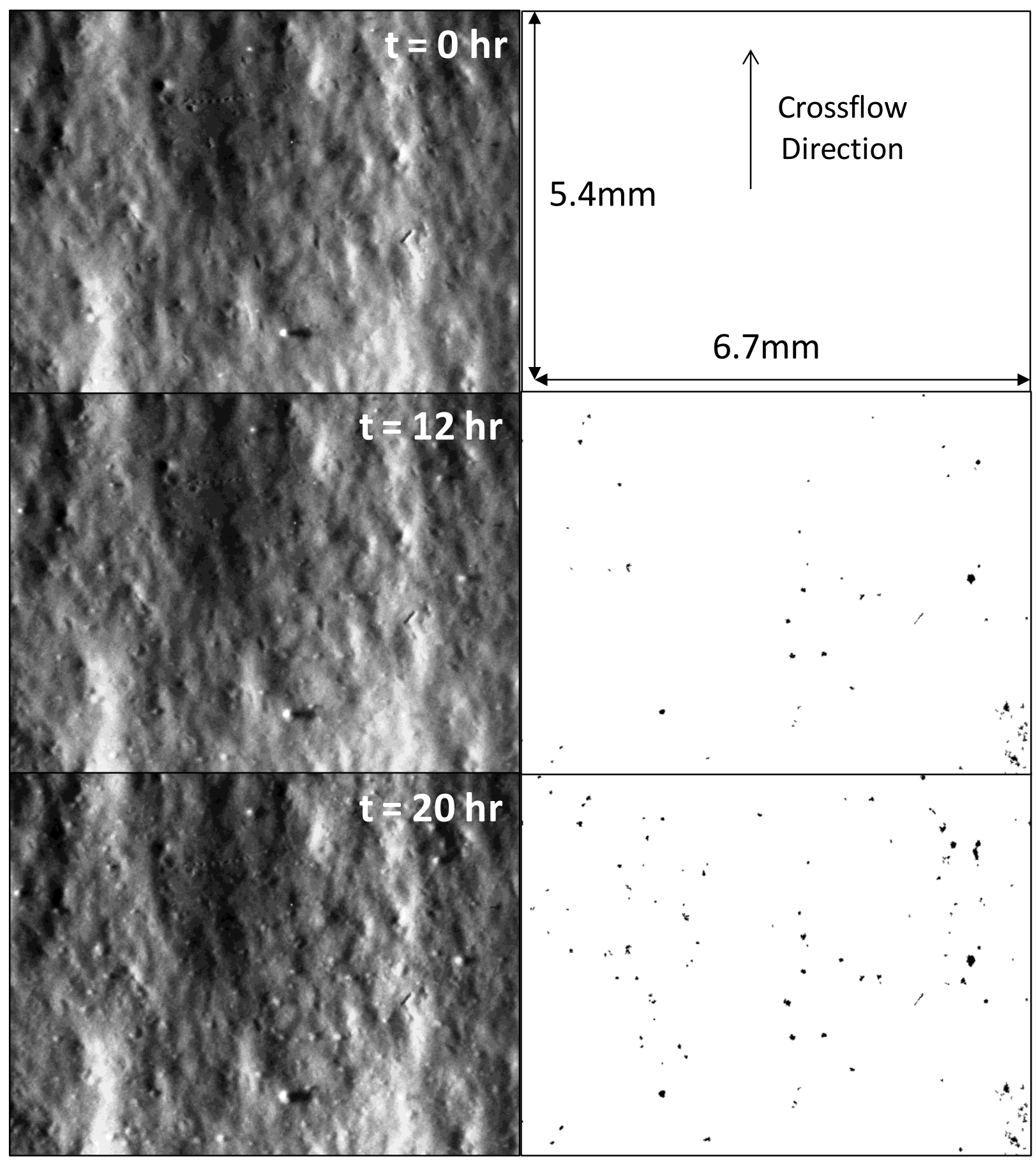

Figure 3. Example of real-time membrane surface images (Left) and segmented binary images (Right) of the grayscale images obtained from silica scaling Run $5\left(\mathrm{SI}_{\mathrm{m}}=3.50\right)$. 


\subsubsection{AFM Surface Analysis of Membrane Samples}

Membrane surface topography was analyzed via atomic force microscopy (AFM) (Dimension Icon, Bruker Corp; Santa Barbara, CA). AFM scans were taken in PeakForce Tapping mode in ambient air using a Bruker ScanAsyst-Air probe (a triangular silicon nitride cantilever with $0.4 \mathrm{~N} / \mathrm{m}$ nominal spring constant, $70 \mathrm{kHz}$ nominal resonance frequency, and 2 nm nominal tip radius). AFM scans ( $20 \mu \mathrm{m} \times 20 \mu \mathrm{m}$ or $50 \mu \mathrm{m} \times 50 \mu \mathrm{m})$ were taken at a scan rate of $0.5-0.9 \mathrm{~Hz}$ for $3-5$ locations on each membrane sample surface; scans were replicated at the same location at $0^{\circ}$ and $90^{\circ}$ to verify that the images were free of directional errors. Membrane surface roughness was quantified in terms of the root-mean-square (RMS) surface roughness, $R_{r m s}=\sqrt{\left[\sum\left(Z_{i}-Z_{\text {avg }}\right)^{2}\right] / N}$ determined from the AFM height distribution data, where $Z_{i}$ is the surface feature height of the $i$ th sample out of $N$ total samples, and $Z_{\text {avg }}$ is the average feature height.

\section{Results and Discussion}

\subsection{Permeate Flux Decline and Early Detection of Scaling}

Measurable permeate flux decline was observed for all the silica scaling tests (Runs 1-5) for which the average silica saturation, at the membrane surface $\left(\overline{\mathrm{SI}}_{\mathrm{m}}\right)$, was in the range of $1.58-$ 3.10 (Fig. 4). Permeate flux decline was gradual for Runs 1-3 for which $\overline{\mathrm{SI}}_{\mathrm{m}}$ was in the range of 1.58-1.94. For example, flux decline was only $\sim 2$ and $3 \%$ by $80 \mathrm{hrs}$ of operation for $\overline{\mathrm{SI}}_{\mathrm{m}}$ of 1.58 and 1.79, respectively, and $\sim 10 \%$ for $\overline{\mathrm{SI}}_{\mathrm{m}}=1.94$. Although flux decline was low $(<5 \%)$ for $\overline{\mathrm{SI}}_{\mathrm{m}}$ $=1.58$ and 1.79 , it reached levels of $\sim 5 \%$ and $\sim 15 \%$ (not shown) after operation of $\sim 200$ hours. At the higher $\overline{\mathrm{SI}}_{\mathrm{m}}$ levels of 2.39 and 3.10, flux decline of $14 \%$ and $19 \%$, respectively, was reached within 20 hours of operation. At the latter highest saturation levels there were two 
noticeable rapid flux decline regions suggesting a high rate of silica scaling; an intermediate moderate flux decline region is also noticed and could be due to silica scale buildup in preferential areas. It is noted that, given the rapid flux decline for the high silica saturation $\left(\overline{\mathrm{SI}}_{\mathrm{m}}\right.$ $=2.39,3.10)$ scaling tests, these runs were terminated after $20-30 \mathrm{hr}$ of operation to avoid excessive system scaling. Here it is noted that RO operation in which silica saturation index is in the above range would likely be infeasible without the utilization of antiscalants specific to retarding silica scaling.

Flux decline behavior for $\overline{\mathrm{SI}}_{\mathrm{m}}=1.58-1.94$ which demonstrated an apparent scale induction period, is consistent with silica polymerization induction time in solution which is expected to increase with decreasing silica supersaturation [42, 44, 73, 81]. It is noted that in field applications it is typical to consider the induction time as that for which measurable permeate flux decline is indicative of the impact of fouling or mineral scaling. This threshold is typically considered to be $\sim 5-10 \%$ flux decline for RO systems [82]. Following the above criterion, it is clear that the observed induction time for silica scaling (Table 3) was $\geq 60 \mathrm{hrs}$ for $\overline{\mathrm{SI}}_{\mathrm{m}}=1.58$ and 1.79 and significantly lower $\left(t_{i n d}=30 \mathrm{hr}\right)$ for $\overline{\mathrm{SI}}_{\mathrm{m}}=1.94$. For the higher silica supersaturation levels the induction time was extremely short $(<1-2 \mathrm{hr})$.

It is emphasized that determination of the onset of silica scaling via flux decline measurements is imprecise. First, silica scaling may occur much earlier than detection of its influence on flux decline. Second, in field application of RO desalination, flux decline may be due to other types of fouling (e.g., particulates, biofouling, or other types of scaling), as well as changes in environmental conditions (e.g., temporally changing water temperature or salinity). In contrast, direct and real time image analysis of the membrane surface shows clearly and unambiguously much earlier detection, relative to flux decline, of the onset and evolution of 
silica scaling in terms of both surface scale coverage (Fig. 4B) and surface density of scale particles (Fig. 4C). For example, detection of silica scaling at a (monitored area) surface coverage of $0.2 \%$ was as early as 79 or $62 \mathrm{hr}$ for $\mathrm{SI}_{\mathrm{m}}$ of 1.60 and 1.93 , respectively. At the higher $\mathrm{SI}_{\mathrm{m}}$ of 2.10, 2.72 and 3.50, $0.2 \%$ area scaling occurred within $22 \mathrm{hr}, 4 \mathrm{hr}$ and $2 \mathrm{hr}$, respectively. While the present study was confined to a system where only silica scaling occurs, application of direct surface imaging to more complex (as may be encountered under field conditions) can provide information about the type of surface scaling/fouling [32, 68].

Table 3. Comparison of the time to reach various possible thresholds as indicators of the onset of scaling for different levels of silica saturation level tested.

\begin{tabular}{cccc}
\hline $\begin{array}{c}\mathbf{S I}_{\mathbf{m}} \text { at the monitored } \\
\text { region and average } \\
\text { value }^{(\mathbf{a})}\left(\overline{\mathrm{SI}}_{\mathrm{m}}\right)\end{array}$ & $\begin{array}{c}\text { Observation Time } \\
\text { for 5\% Flux Decline } \\
\text { (hr) }\end{array}$ & $\begin{array}{c}\text { Scale Coverage at 5\% } \\
\text { Flux Decline }(\%)\end{array}$ & $\begin{array}{c}\text { Silica SND at 5\% Flux } \\
\text { Decline }\left(\# / \mathbf{m m}^{2}\right)\end{array}$ \\
\hline $1.60(1.58)$ & 165 & 3.50 & 16.0 \\
$1.93(1.79)$ & 92 & 0.95 & 9.6 \\
$2.10(1.94)$ & 52 & 9.95 & 15.9 \\
$2.72(2.39)$ & 1.3 & 0.05 & 0.13 \\
$3.50(3.10)$ & 0.14 & 0.01 & 0.02 \\
\hline
\end{tabular}

(a) The $\overline{\mathrm{SI}}_{\mathrm{m}}$ value in parentheses is the axially average value in the membrane channel.

A threshold for detecting the onset of silica scaling can also be set based on the SND. For example, for the local $\mathrm{SI}_{\mathrm{m}}$ range of 1.60-3.50 (i.e., at the optically monitored membrane region), silica scale detection at the SND threshold of 50 silica particles $/ \mathrm{cm}^{2}$ (Fig. 4C) was significantly earlier (by a factor of 2-7) relative to the typical 5\% flux decline threshold (Table 3, Fig. 5). It has been previously suggested that the majority of silica nuclei are formed during the induction period [44], and that particle nucleation and growth precedes gelling [37]. This appeared to be the case as particles were detected and tracked, although SEM imaging revealed gel-like silica films also eventually formed for all $\mathrm{SI}_{\mathrm{m}}$ levels (Section 3.3, Figs. 9-11, 14). Following of the evolution of the silica particle surface number density (Fig. 4c) and growth (Section 3.2), in the monitored region, was feasible at the early stages of silica scaling (i.e., up to 20-50 hours) 
(Figs. 4B-C, 7). At high silica saturation $\left(\mathrm{SI}_{\mathrm{m}}\right.$ above $\left.~ 2.72\right)$ significant flux decline was observed which was clearly beyond what could be attributed to surface area coverage by particles (Fig. 4B). It is emphasized that one should not expect to observe congruent (i.e., 1:1) overall percent flux decline (for the PFRO channel) with percent surface scale coverage in the small monitored membrane area given: (a) the stochastic nature of mineral scaling, (b) differences in silica saturation between the local monitored area and other sections of the membrane [69, 70], and (c) silica gel (Section 3.3) which contributes to the observed flux decline is not tracked by surface optical imaging. SEM images (Section 3.3) and EDS analysis reveal the presence of a silica gel layer (which can be porous, Fig. 11H) with embedded silica particles. However, early detection of particles relative to flux decline is apparent in the low silica saturation runs $\left(\mathrm{SI}_{\mathrm{m}}=1.6-2.1\right)$. The gel layer does contribute to blockage of the membrane surface; however, real time analysis of surface silica gel coverage is not feasible using currently available (real time) surface analysis methods. The use of batch studies (i.e., multiple scaling experiments of different time periods with surface analysis of membranes sacrificed at the end of each experiment) while feasible is a daunting and also a challenging task given the stochastic nature of mineral scaling . 
(A)

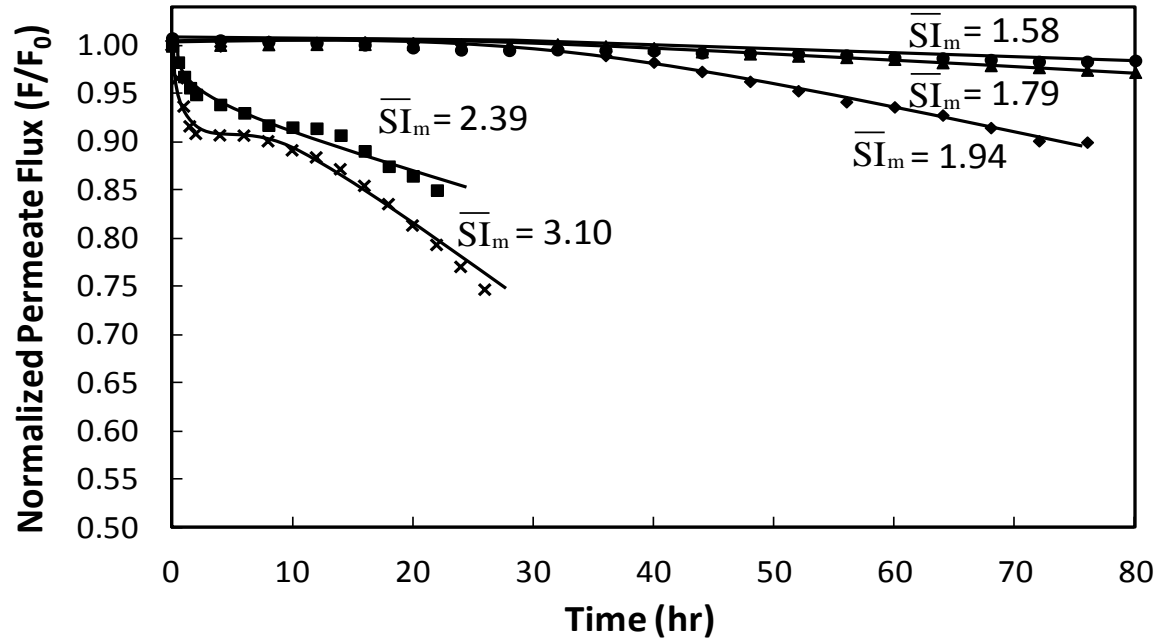

(B)

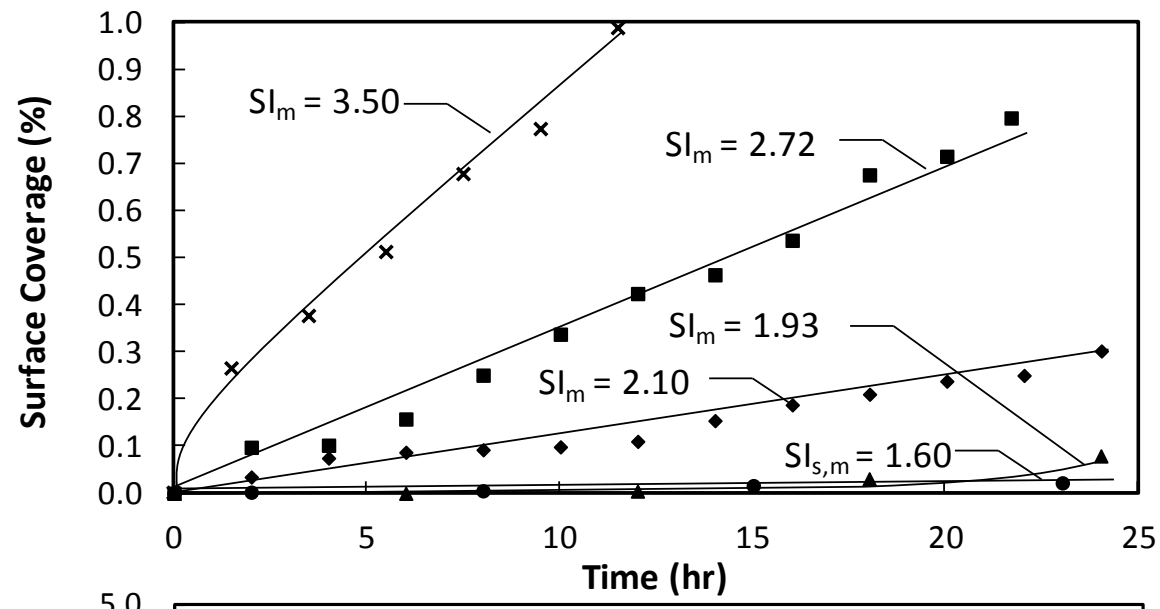

(C)

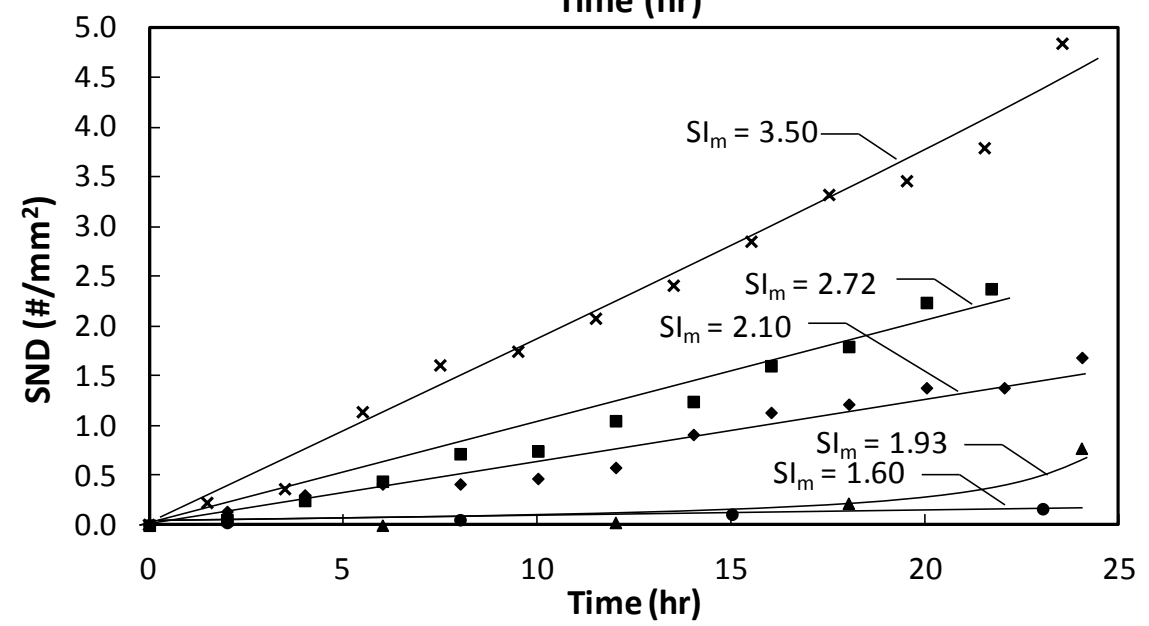

Figure 4. Normalized permeate flux (overall) (A), silica scale surface coverage (B) and particle surface number density (SND) (C) for the monitored membrane area for scaling runs at $\mathrm{SI}_{\mathrm{m}}=$ 1.60-3.50 $\left(\overline{\mathrm{SI}}_{\mathrm{m}}=1.58-3.10\right)$. (Notes: the SND is shown for the first $25 \mathrm{hr}$ during which distinct particles could be distinguished. $\mathrm{F}=$ permeate flux at time $\mathrm{t}, \mathrm{F}_{0}=$ initial permeate flux (Table 2)). 


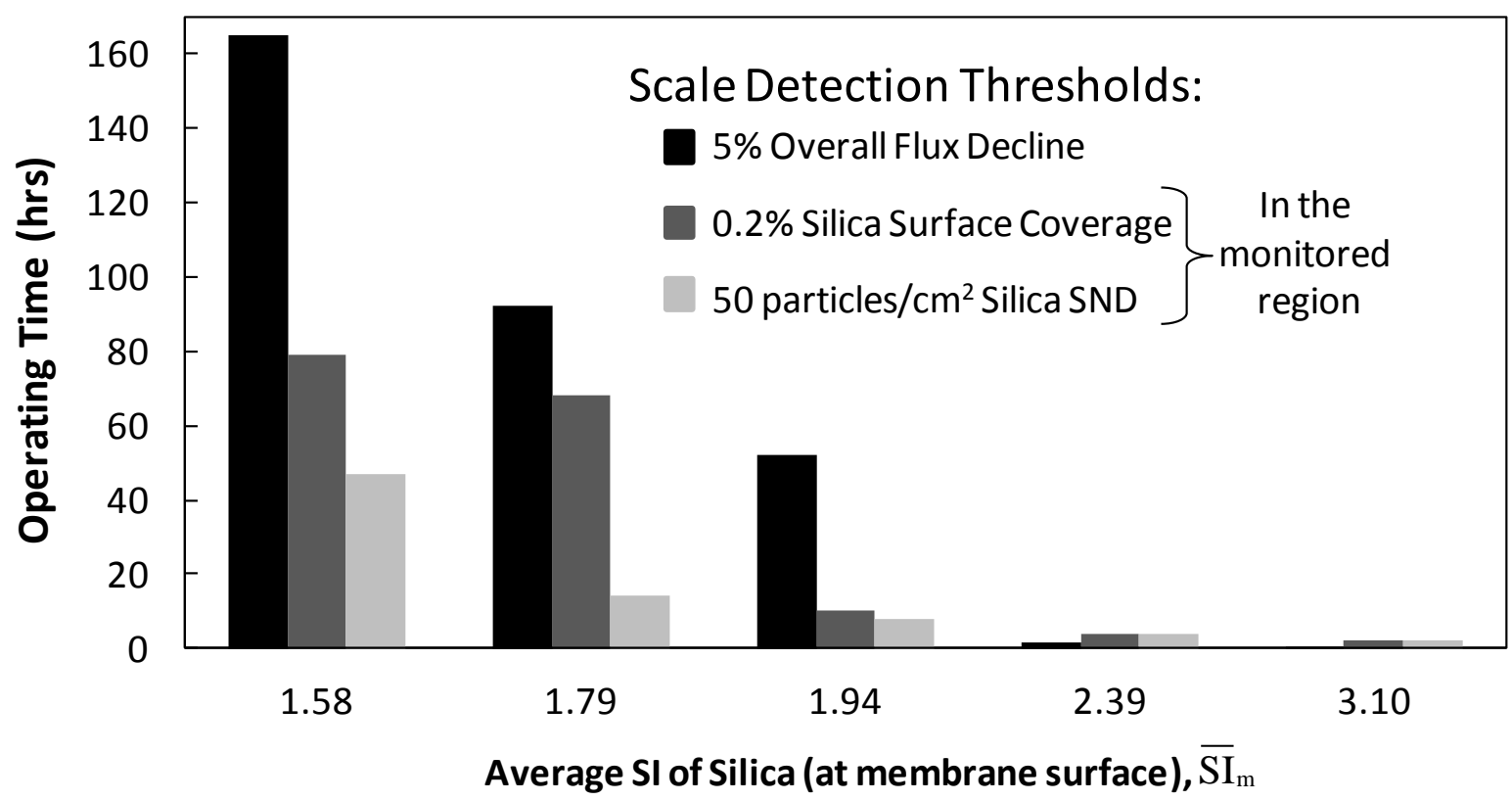

Figure 5. Comparison of operation times prior to different detection thresholds being met for early scale detection. Note: the $\mathrm{SI}_{\mathrm{m}}$ in the monitored region (where surface coverage and SND were measured) were monitored at $\mathrm{SI}_{\mathrm{m}}=1.60,1.93,2.10,2.72$, and 3.50, corresponding to the average levels in the range of 1.58-3.10.

\subsection{Nucleation and Growth Kinetics of Silica Scale Particles}

It is instructive to quantify the initial nucleation rates (when the surface is sparsely populated with silica particles and particle growth domains do not overlap) based on the membrane surface images following the approach in [84]. It should be recognized, however, that the current membrane surface observation technique (as well as others) is incapable of real-time imaging of nano-size nuclei. Nonetheless, observed rate of change of silica surface number density correlates directly with the silica particles nucleation rate given that every site of identified silica particle is also the site at which the tracked particle was nucleated. Accordingly, here the detection rate of silica particles (or observed nucleation rate), $J_{N}$, as determined from the silica SND $(\bar{N})$ rate of change, $\left(J_{N}^{0}\right)$ obs, and the fractional membrane surface area covered by scale $(\phi$ 
) , is given as $J_{N}=(\mathrm{d} \bar{N} / \mathrm{dt}) /(1-\phi)=\left(J_{N}^{0}\right)_{\text {obs }} /(1-\phi)$. The calculated nucleation rates can then be compared with the nucleation rate predicted based on the classical nucleation theory [83, 84]:

$$
J_{N}=A_{N} \exp \left(-\frac{a_{N}}{(\ln (S I))^{2}}\right)
$$

where $A_{N}$ is a nucleation rate constant, $S I$ is the silica saturation index, and $a_{N}=\left(16 \pi \gamma^{3} v^{2} f(\theta)\right) /\left(3 k_{b}^{3} T^{3}\right)$, where $\gamma$ is the specific surface energy at the crystal/particle-solution interface $\left(\mathrm{J} / \mathrm{m}^{2}\right), v$ is the molecular volume $\left(\mathrm{cm}^{3} / \mathrm{mol}\right)$, and $f(\theta)$ is the heterogeneous nucleation factor (where $\theta$ varies between 0 and 1$), k_{b}$ is the Boltzmann constant, and $\mathrm{T}$ is temperature $(\mathrm{K})$ [84]. As shown in Fig. 6, Eq. (3) fits the experimental data reasonably well with the extracted parameters values of $A_{N}=20.5 \mathrm{~cm}^{-2} \mathrm{hr}^{-1}$ and $a_{N}=0.69$; the value of $a_{N}$ is in reasonable agreement with the value of $0.47 \pm 0.1$ recently reported for silica bulk phase nucleation (when corrected for temperature) [85].

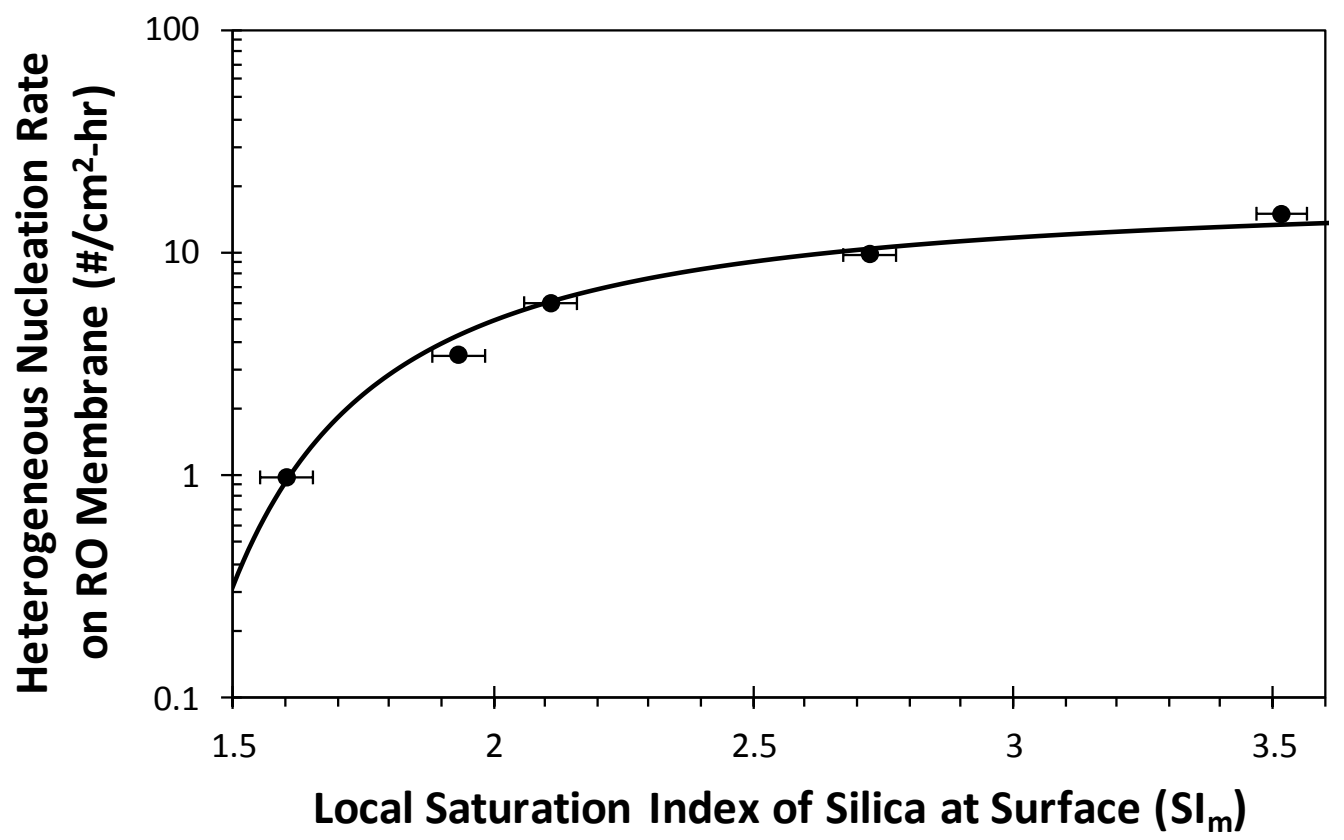

Figure 6. Observed nucleation rates for silica particle nucleation and best fit curve from classical nucleation theory. Error bars represent concentration range for monitored membrane viewing area. 
The growth of the nucleated silica particles, prior to their incorporation/growth into the silica gel layer, was evaluated by analyzing the size evolution of individual silica particles. The particle size was quantified by the particle effective diameter, $d_{e q}$, defined as $d_{e q}=\sqrt{4 A_{p} / \pi}$ where $A_{p}$ is the projected particle surface area. As shown in Fig. 7, for a given $\mathrm{SI}_{\mathrm{m}}$, silica particle growth was essentially linear with time. The growth rate of silica particles, expressed as $d\left(d_{e q}\right) / d t$, increased by a factor of up to $\sim 23$ as the $\mathrm{SI}_{\mathrm{m}}$ increased from 1.60 to 3.50 . It is noted that the constant silica particle growth rate is suggestive of diffusional growth that can be described by the following classical model $[9,10]$ :

$$
r_{d}=\frac{d\left(d_{e q}\right)}{d t}=\frac{2 k\left(C_{m}-C_{s}\right)}{\rho_{p}}
$$

where $k$ is the particle-fluid mass transfer coefficient, $\rho_{p}$ is the particle mass density (taken to be $2.196 \mathrm{~g} / \mathrm{cm}^{3}$ [86]), and $C_{s}$ and $C_{m}$ are the silica concentrations at saturation and at the particlesolution interface, respectively. As shown in Figure 8 , the silica particle growth rate $(d(d e q) / d t)$ varied linearly with the concentration driving force (Eq. 4); for the present channel hydrodynamics (i.e., $\mathrm{Re}=107$ ) the corresponding mass transfer coefficient $(k)$ was estimated to be $9.2 \times 10^{-6} \mathrm{~m} / \mathrm{s}$. It is noted that below $\left(C_{m}-C_{s}\right) \approx 40 \mathrm{mg} / \mathrm{L}$ the particle growth rate was too slow to ascertain to a reasonable level of confidence; at the above range particle growth could be surface reaction controlled, but further work would be needed to evaluate this hypothesis. 


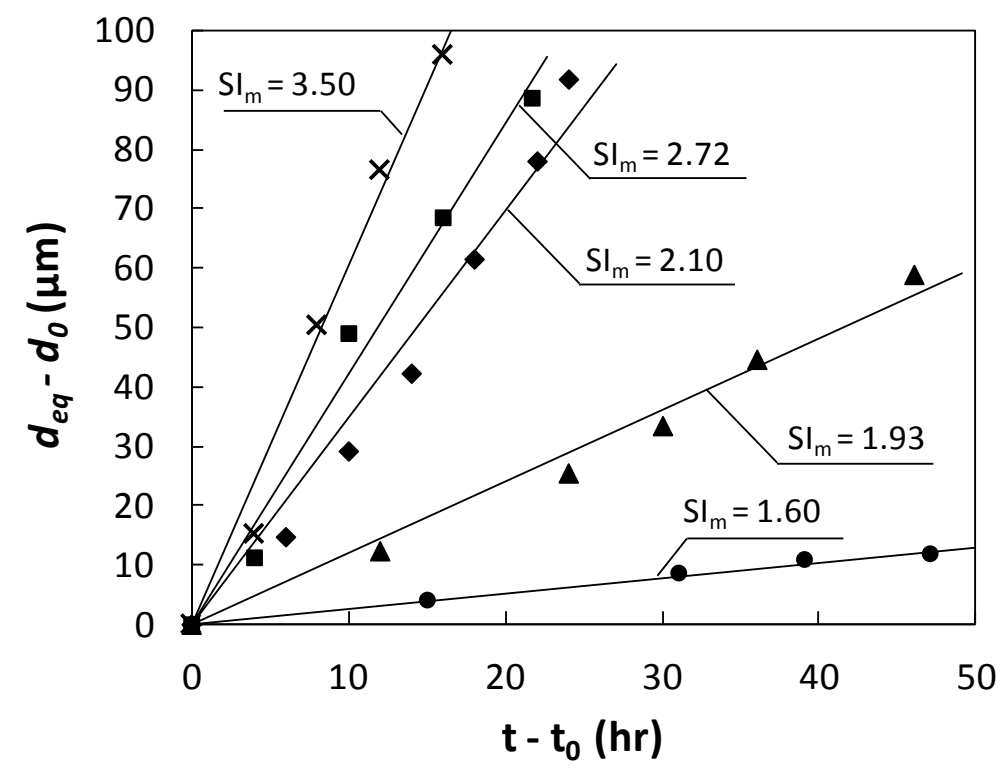

Figure 7. Silica particle growth over time ( $\mathrm{t}_{0}=$ initial observation time for each particle, $d_{0}$ is the initial observed equivalent particle diameter).

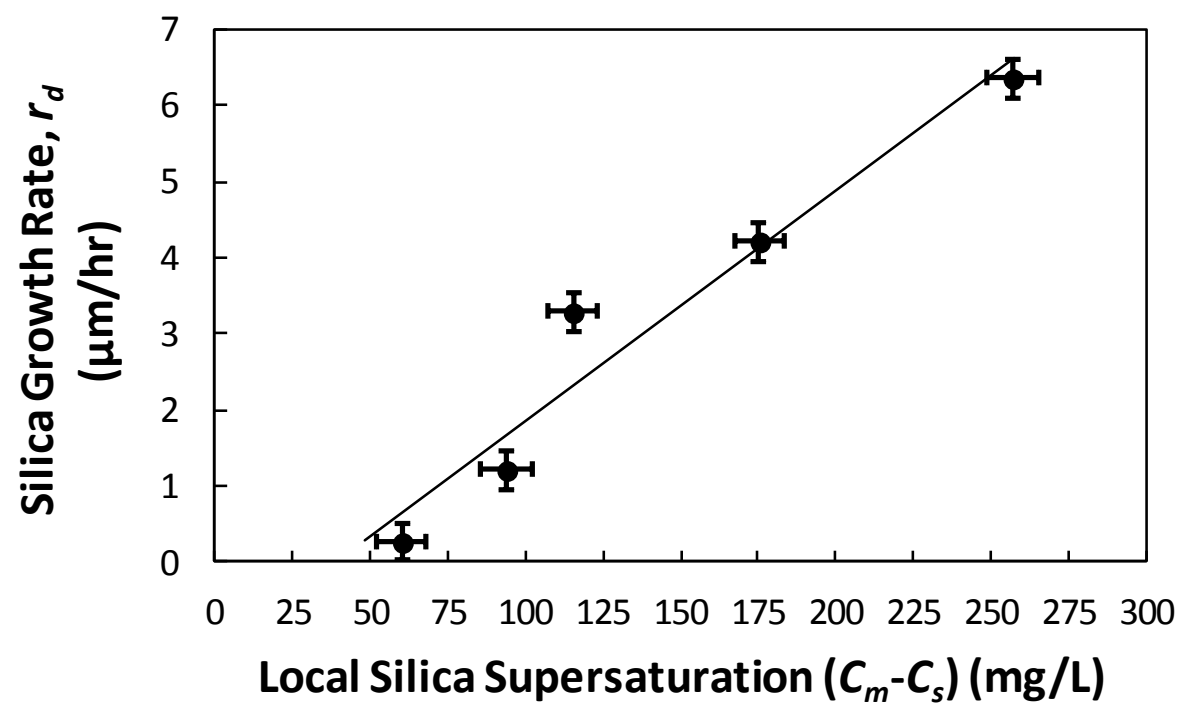

Figure 8. Correlation of silica particle growth rate with the concentration driving force for diffusional growth for $\mathrm{SI}_{\mathrm{m}}=1.60-3.50$ (i.e., difference between silica concentration at the membrane surface and silica solubility). (The horizontal and vertical bars represent the variation in local saturation levels and differences in individual particle growth rates, respectively). 


\subsection{Silica Scale Morphology}

The scaled membrane SEM images revealed a range of surface morphologies, showing the presence of silica particles and agglomerates as well as a "gel" like coverage (Figs. 9-11, 14). The scaled membrane surface images for $\mathrm{SI}_{\mathrm{m}}=1.60-2.72$ (Runs 1-4) revealed strands of silica scale (silica gel) aligned in the flow direction (Fig. 10A,D) that apparently developed from silica particles. The extent of surface coverage and size of silica particles increased at the higher $\mathrm{SI}_{\mathrm{m}}$ of 2.10, 2.72 and 3.50 (Runs 3, 4 and 5), and the particles were primarily dispersed and roughly spherical in shape (Fig. 10A,B,G,H). Elemental analysis (EDS) confirmed the presence of Si and O atoms (Figs. 9F,I \& 10C,F,I) consistent with the presence of silica scale. As expected, the $\mathrm{Si}$ EDS peaks for the lowest silica saturation levels of 1.60 and 1.93 (Runs 1 and 2) were less pronounced than for runs at higher silica saturation of 2.10-3.50 (Runs 3-5). At the lowest $\mathrm{SI}_{\mathrm{m}}$ of 1.60 (Run 1) there appeared to be a widespread and relatively uniform film of presumably silica gel (Fig. 11D-F), with sparsely dispersed aggregates of silica particles (Fig. 9D,E). At the higher $\mathrm{SI}_{\mathrm{m}}$ of 1.93 (Figs. 9G,H), the SEM images suggest a significantly higher density of silica particles that seem to be embedded within and also present above the silica gel film (Fig. 9G,H). 


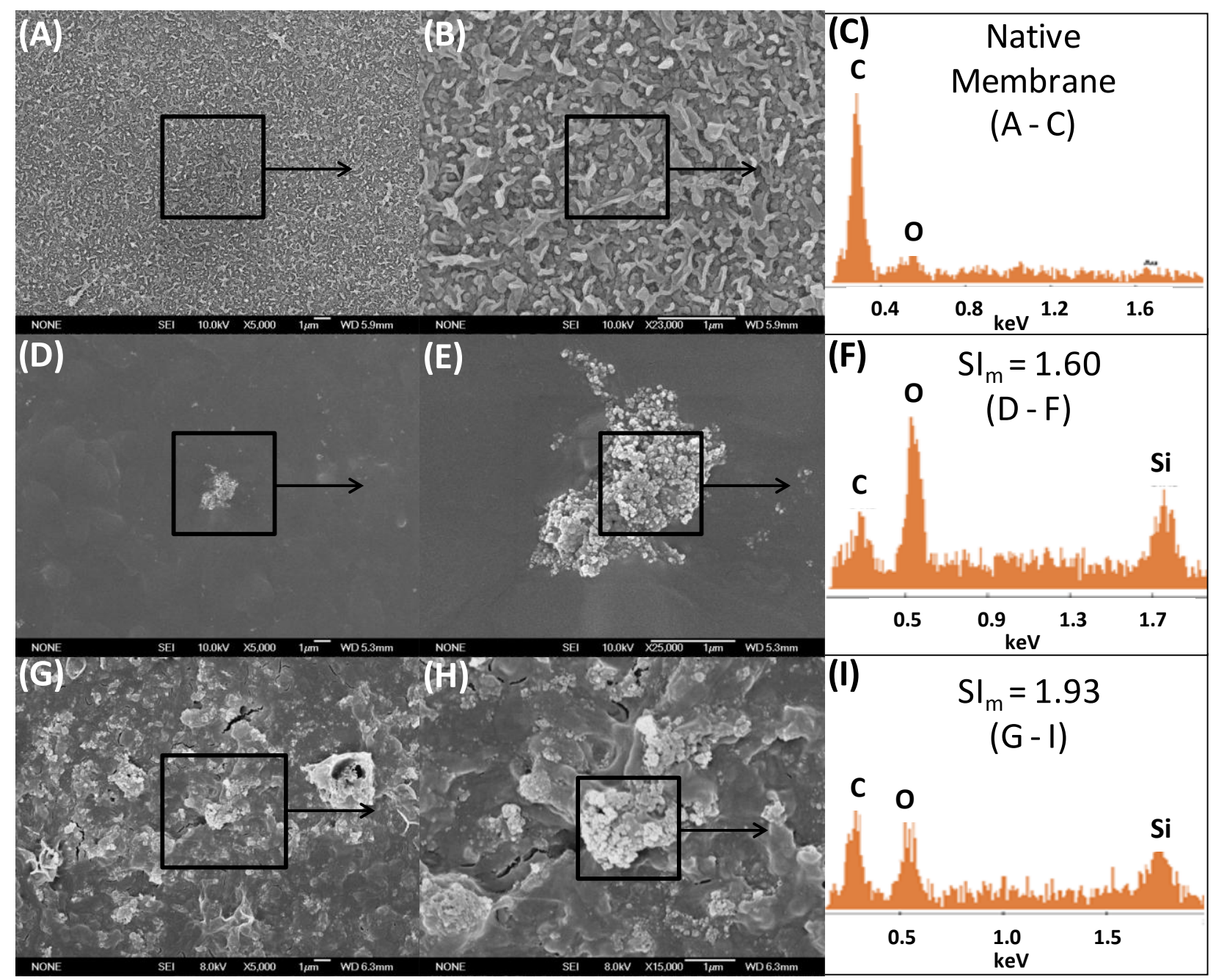

Figure 9. SEM images and corresponding EDS spectra for native (i.e., clean) RO membrane (AC) and for membranes scaled at $\mathrm{SI}_{\mathrm{m}}=1.60(\mathrm{D}-\mathrm{F})$, and $\mathrm{SI}_{\mathrm{m}}=1.93(\mathrm{G}-\mathrm{I})$.

As the $\mathrm{SI}_{\mathrm{m}}$ increased to 2.10 (Run 3) the surface appeared to be populated by larger discrete particles of about $1-5 \mu \mathrm{m}$ in diameter, as well as a rough film (Fig. 10A-C). For the higher $\mathrm{SI}_{\mathrm{m}}$ of 2.72 (Run 4), which was of short duration $(\sim 20 \mathrm{hr})$ relative to the other runs, there are patches of silica gel (observed via SEM) (Fig. 10D), and a relatively uniform film in between the protruding silica scale patches, that appears to be embedded with silica aggregates (Fig. 10E,F). Discrete particles in the size range of $1-10 \mu \mathrm{m}$ were also visible. For the scaling test at the highest $\mathrm{SI}_{\mathrm{m}}$ of 3.50 (Run 5), which was kept short ( $25 \mathrm{hr}$ ) due to the severe fouling and rapid 
flux decline (Fig. 4), surface scaling was in the form of widespread silica "gel" layer with larger embedded silica particles $(\sim 10-30 \mu \mathrm{m})$ (Figs. 10G,H, 11); however, in contrast to the silica scale morphologies at lower $\mathrm{SI}_{\mathrm{m}}$, the silica scalant layer appeared to be porous and rough (Figs. 10H, 11G-I), which could possibly be due to insufficient time for film rearrangement given the relatively short duration of this run. For all supersaturation levels, a "gel" film eventually formed resulting in a widespread degree of surface coverage, as observed in SEM images (Figs. 9-11, 14).

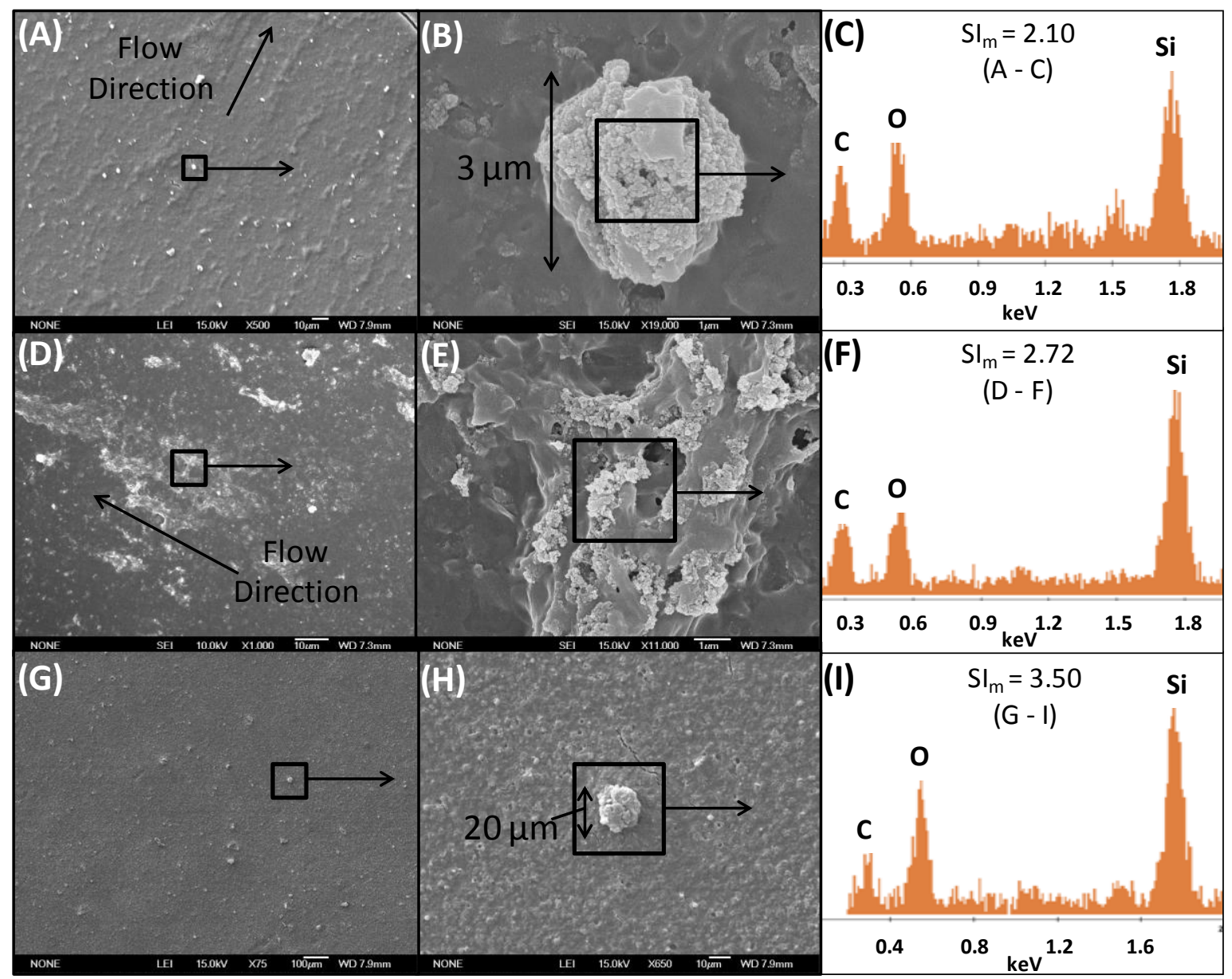

Figure 10. SEM images at end of scaling tests, and corresponding EDS spectra for membranes scaled at $\mathrm{SI}_{\mathrm{m}}=2.10$ (Run 3) (A-C), $\mathrm{SI}_{\mathrm{m}}=2.72$ (Run 4) (D-F), and $\mathrm{SI}_{\mathrm{m}}=3.50$ (Run 5) (G-I). 

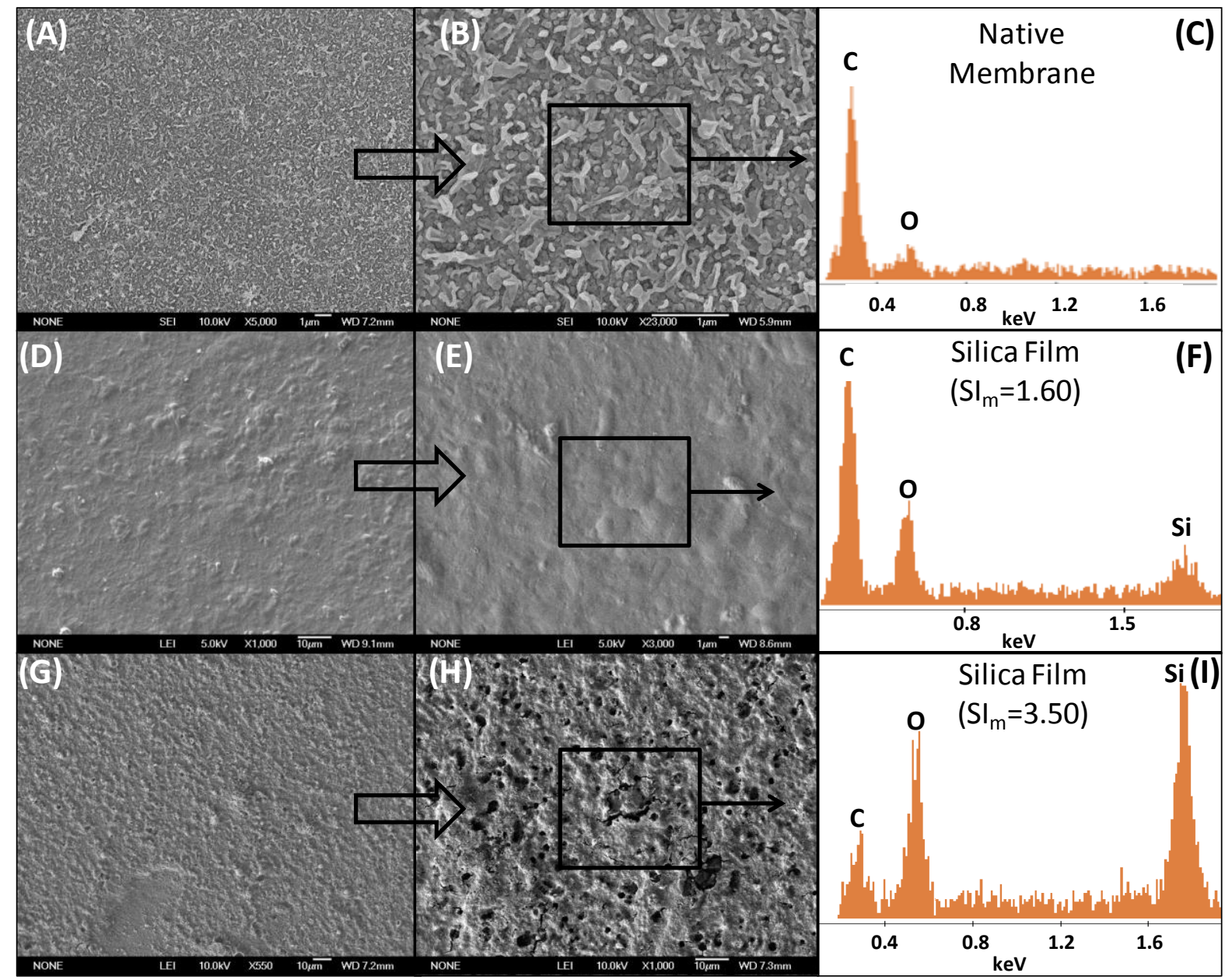

Figure 11. SEM images at end of scaling tests, and corresponding EDS spectra for native (i.e., clean) membrane (A-C) and gel-like film regions for membranes scaled at $\mathrm{SI}_{\mathrm{m}}=1.60$ (Run 1) (DF) and $\mathrm{SI}_{\mathrm{m}}=3.50$ (Run 5) (G-I). 


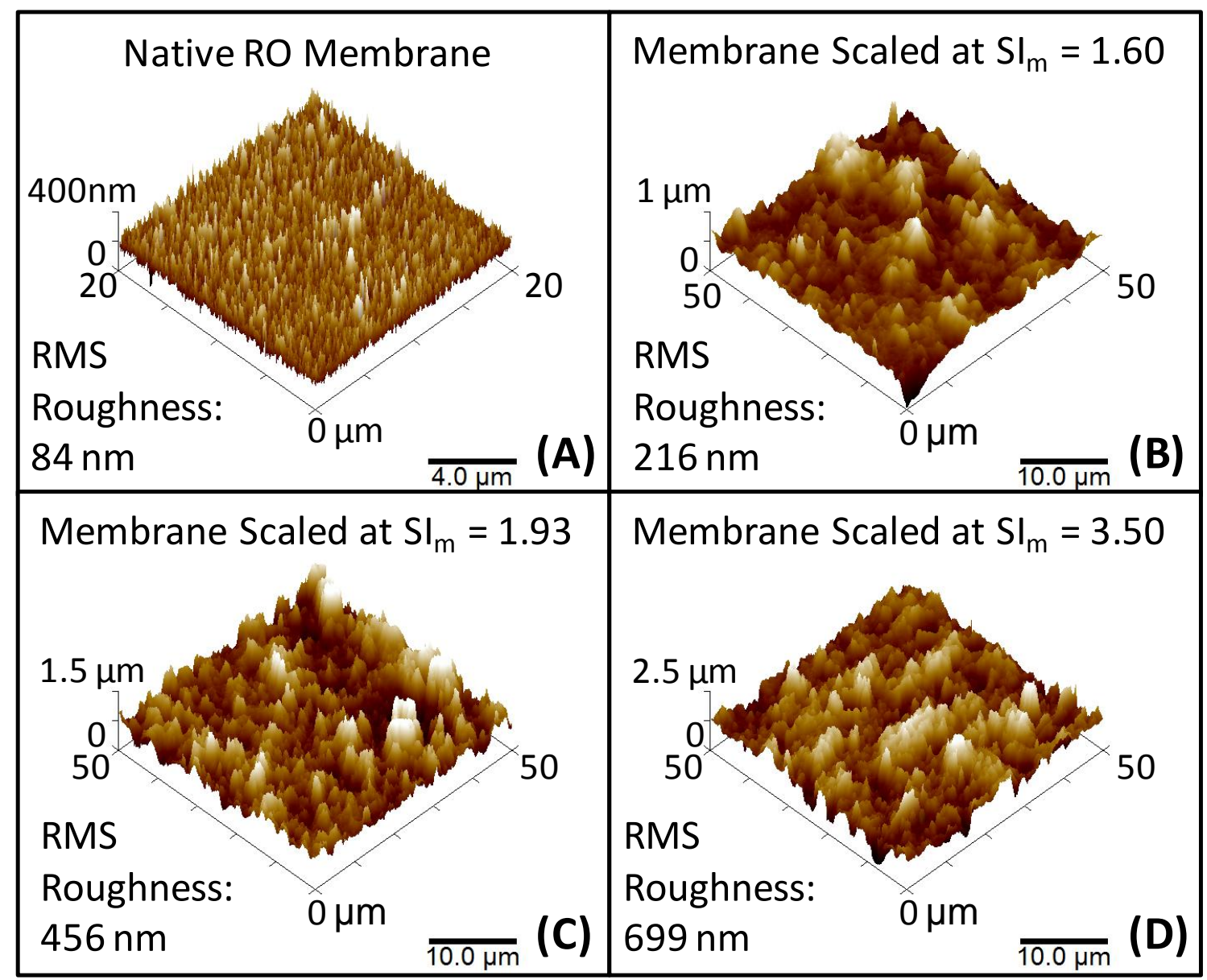

Figure 12. 3-D AFM images for feature heights for membranes scaled with silica at various SI levels (B-D) relative to the native (clean) RO membrane (A). Vertical and horizontal axes indicate the range of feature heights and planar location, respectively. RMS roughness values are inset. Scans were taken after the end of the scaling experiments.

Surface roughness (determined via AFM) of the silica scaled membranes increased with rising level of silica supersaturation. Correspondingly, the surface feature heights also increased with a feature height distribution that became broader, at higher $\mathrm{SI}_{\mathrm{m}}$ levels (Figs. 12 \& 13). For example, the native membrane RMS surface roughness was $84 \mathrm{~nm}$ with a mode of the feature height distribution of $\sim 200 \mathrm{~nm}$ with a distribution width of $\sim 500 \mathrm{~nm}$ (Figs. $12 \&$ 13). In contrast, the membranes scaled at $\mathrm{SI}_{\mathrm{m}}$ of 1.60-3.50 had a significantly higher RMS surface roughness in the range of 216-699 $\mathrm{nm}$ and feature height mode of $900 \mathrm{~nm}-2500 \mathrm{~nm}$ (Figs. 12 \& 13). It is 
noted that the broader feature height distributions are consistent with the presence of large aggregates (Figs. $9 \& \mathbf{1 0}$ ) at the higher levels of silica supersaturation.
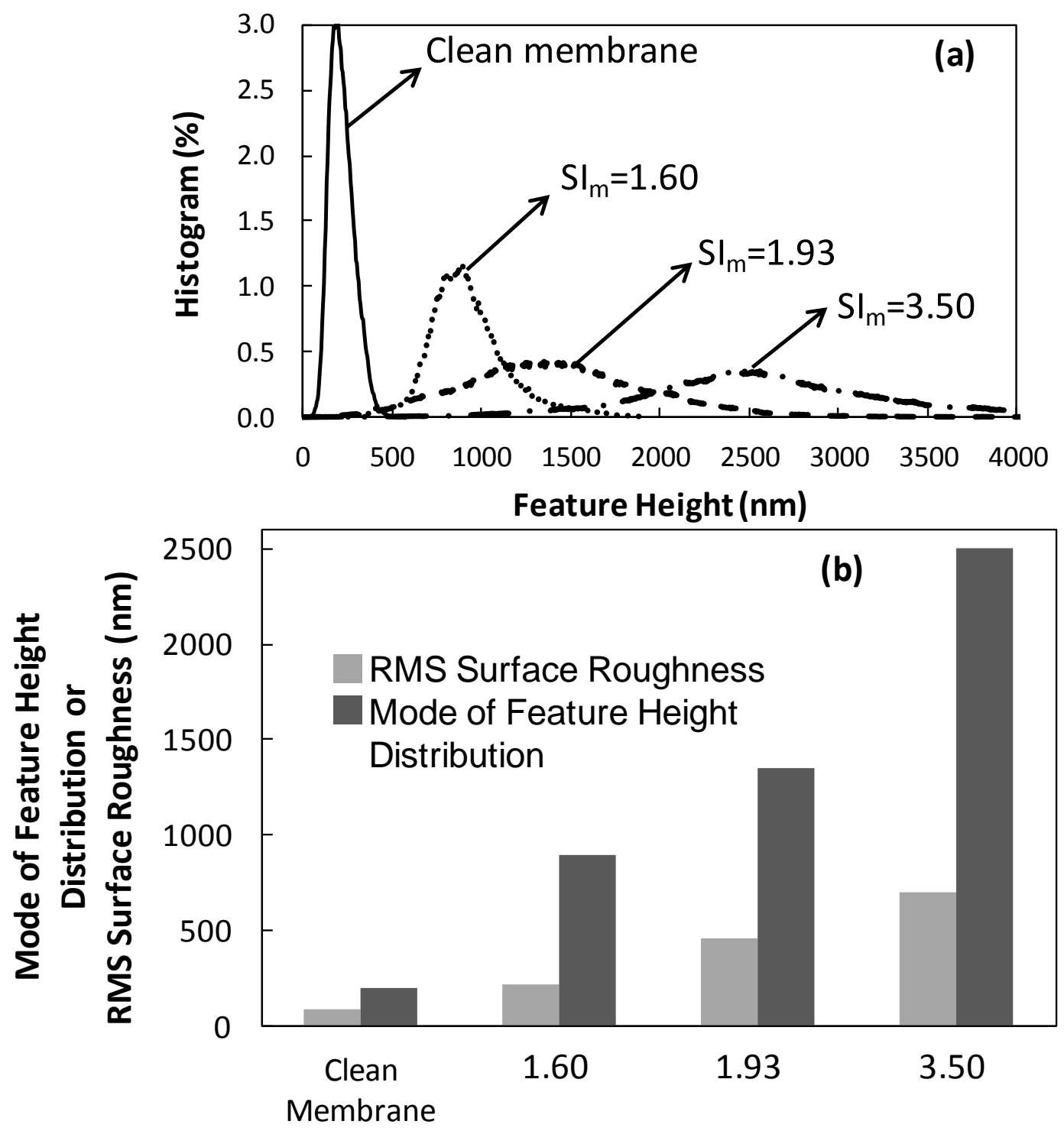

Silica Saturation Index at the Membrane Surface, $\mathrm{SI}_{\mathrm{m}}$

Figure 13. (a) Feature height histograms and (b) mode of the feature heights distribution and RMS surface roughness for membranes scaled at different $\mathrm{SI}_{\mathrm{m}}$ levels and for a clean membrane.

The silica scale layer is likely to be thin at the low $\mathrm{SI}_{\mathrm{m}}$ levels and there are regions of low coverage even at high silica saturation as suggested by the AFM analysis (Figs. $12 \&$ 13). A 
confirmation of regions of thin silica layers on the RO membrane was undertaken via imaging of the sectioned membranes from Runs $1 \&$ 2, via dual beam FIB-SEM. As revealed in Fig. 14, a foulant layer is present above the active membrane layer (Fig. 14). The scalant layer had a thickness in the range of $\sim 250-300 \mathrm{~nm}$ for $\mathrm{SI}_{\mathrm{m}}=1.60$ (Fig. 14D) with uneven thickness for $\mathrm{SI}_{\mathrm{m}}=1.93$ ranging from $\sim 300-700 \mathrm{~nm}$ (Fig. 14F). The "darker" dense layer between the scalant layer and the sponge-like (polysulfone) membrane support is identified as the polyamide RO membrane separation layer, with thicknesses in the range of 70-150 nm.

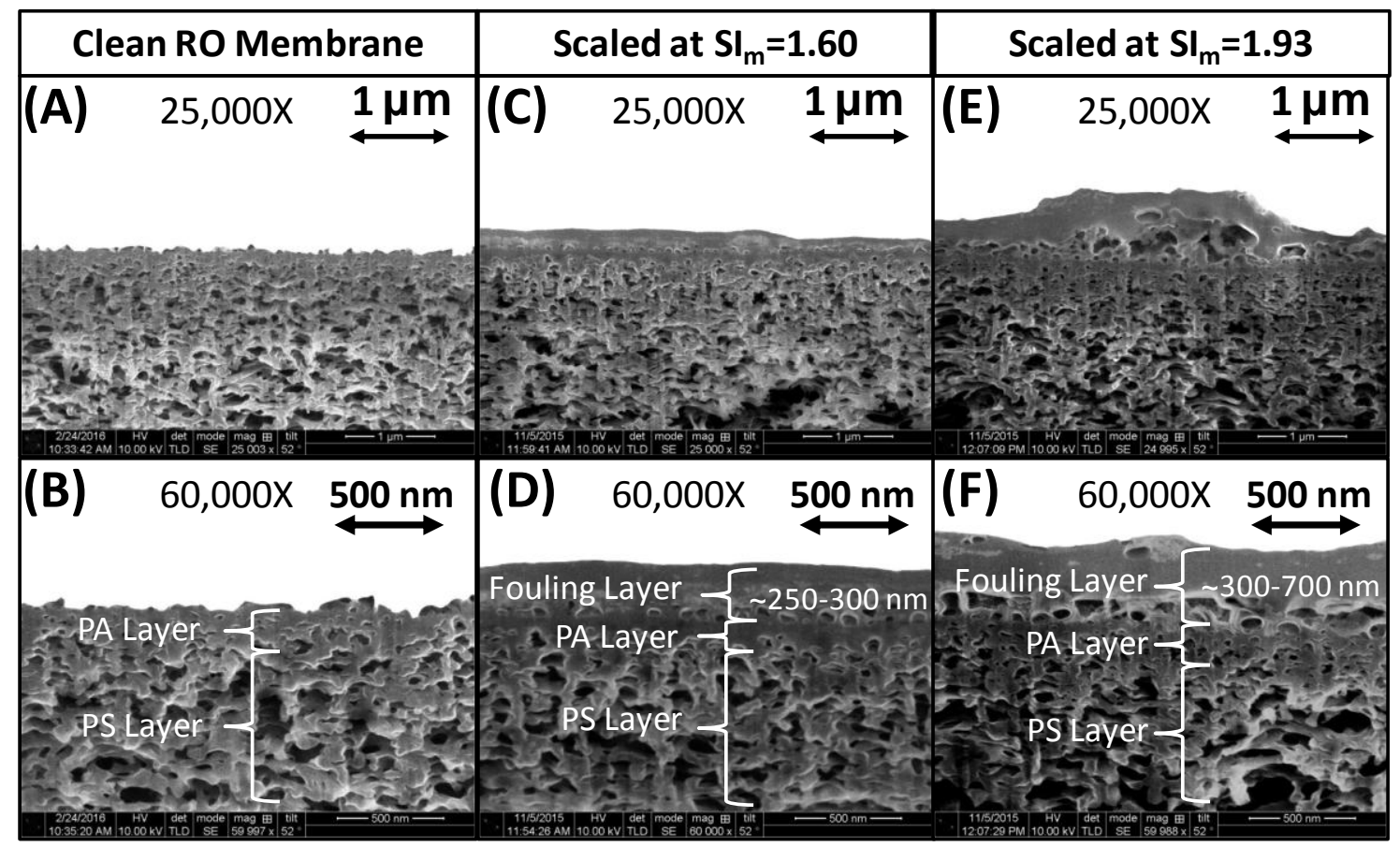

Figure 14. Examples of membrane cross-section images obtained via FIB/SEM (Magnification A-C: 25,000X, D-F: 60,000X). A \& B are the native (clean) RO membrane whereas C, D, and E, $\mathrm{F}$ are for membranes scaled at $\mathrm{SI}_{\mathrm{m}}$ of 1.60 and 1.93 , respectively. Note that these end of run images reveal a silica scale layer on top of the active membrane layer.

\section{Conclusions}

Silica scaling of RO membranes was investigated via real-time direct surface imaging, flux decline measurements, and SEM imaging over a range of silica supersaturation. The studies, 
conducted in an optically transparent RO plate-and-frame cell, demonstrated detection of silica scaling that is significantly earlier (by a factor of 2-7) than suggested by the detection of measurable flux decline (i.e., $\geq 5 \%$ ). Real-time membrane surface image analysis also enabled quantification of silica scaling kinetics in terms of both percent scaled area and number density of silica particles. The rate of silica particle nucleation on the membrane surface appeared to follow classical nucleation theory with the growth of individual silica particles governed primarily by a classical diffusion mechanism. Based on present optical monitoring, SEM imaging and AFM analysis, it appears that silica scaling occurs through the formation of primary silica particles and their agglomerates $(\sim 1-30 \mu \mathrm{m})$, which were generally larger at higher supersaturation levels, as well as a silica gel-like film, which also contributes to flux decline, that can be smooth or rough with embedded silica particles. At low levels of silica supersaturations, the silica gel film was smoother and appeared less porous than that formed at high supersaturation. At the higher supersaturation levels (i.e., $\mathrm{SI}_{\mathrm{m}}=2.72-3.50, \overline{\mathrm{SI}}_{\mathrm{m}}=2.39-3.10$ ), silica scaling led to rapid permeate flux decline, attributed to primarily silica gel formation.

The silica scale layer thickness was in the range of $0.1-3.5 \mu \mathrm{m}$ and increased with silica supersaturation. Over the range of silica supersaturation (i.e., $\mathrm{SI}_{\mathrm{m}}=1.60-3.50$ ), the membrane surface roughness increased by a factor of $2.6-8.3$ relative to the native membrane. It is noted that the present approach to real time scale monitoring may be well suited for tracking the early development of silica scale which is associated with the appearance of silica particles. Developing the approach for monitoring silica scaling in RO plants under field conditions, however, will require more studies to assess the ability to detect silica scaling in combination with other scalants/foulants. 


\section{Acknowledgements}

This work was funded, in part, through grants by the Electric Power Research Institute (Grant ID 071620), the California Department of Water Resources (46-4120, RD-2006-09 and 14-251550), U.S. Bureau of Reclamation (R13AC80025), and the UCLA Water Technology Research (WaTeR) Center. The presented material is based, in part, upon research performed in a UCLA WaTeR Center laboratory renovated through National Science Foundation Grant No. 0963183, which is an award funded under the American Recovery and Reinvestment Act of 2009 (ARRA).

\section{References}

[1] L.F. Greenlee, D.F. Lawler, B.D. Freeman, B. Marrot, P. Moulin, Reverse osmosis desalination: Water sources, technology, and today's challenges, Water Research, 43 (2009) 2317-2348.

[2] A. Rahardianto, B.C. McCool, Y. Cohen, Reverse Osmosis Desalting of Inland Brackish Water of High Gypsum Scaling Propensity: Kinetics and Mitigation of Membrane Mineral Scaling, Environmental Science \& Technology, 42 (2008) 4292-4297.

[3] B.C. McCool, A. Rahardianto, J. Faria, K. Kovac, D. Lara, Y. Cohen, Feasibility of reverse osmosis desalination of brackish agricultural drainage water in the San Joaquin Valley, Desalination, 261 (2010) 240-250.

[4] A. Rahardianto, B. C. McCool, Y. Cohen, Accelerated desupersaturation of reverse osmosis concentrate by chemically-enhanced seeded precipitation, Desalination, 264 (2010) 256-267.

[5] B.C. McCool, A. Rahardianto, J.I. Faria, Y. Cohen, Evaluation of chemically-enhanced seeded precipitation of RO concentrate for high recovery desalting of high salinity brackish water, Desalination, 317 (2013) 116-126.

[6] S.J. Altman, R.P. Jensen, M.A. Cappelle, A.L. Sanchez, R.L. Everett, H.L. Anderson Jr., L.K. McGrath, Membrane treatment of side-stream cooling tower water for reduction of water usage, Desalination, 285 (2012) 177-183.

[7] J. Löwenberg, J.A. Baum, Y-S. Zimmermann, C. Groot, W. van den Broek, T. Wintgens, Comparison of pre-treatment technologies toward improving reverse osmosis desalination of cooling tower blow down, Desalination, 357 (2015) 140-149.

[8] A. Rahardianto, W.-Y. Shih, R.-W. Lee, Y. Cohen, Diagnostic characterization of gypsum scale formation and control in membrane desalination of brackish water, Journal of Membrane Science, 279 (2006) 655-668.

[9] M. Brusilovsky, J. Borden, D. Hasson, Flux decline due to gypsum precipitation on RO membranes, Desalination, 86 (1992) 187-222.

[10] M. Uchymiak, E. Lyster, J. Glater, Y. Cohen, Kinetics of gypsum crystal growth on a reverse osmosis membrane, Journal of Membrane Science, 314 (2008) 163-172.

[11] J. Gilron, D. Hasson, Calcium sulphate fouling of reverse osmosis membranes: flux decline mechanism, Chemical Engineering Science, 42 (1987) 2351-2360. 
[12] M. Uchymiak, A. Rahardianto, E. Lyster, J. Glater, Y. Cohen, A novel RO ex situ scale observation detector (EXSOD) for mineral scale characterization and early detection, Journal of Membrane Science, 291 (2007) 86-95.

[13] A. Rahardianto, J. Gao, C. J. Gabelich, M. D. Williams, Y. Cohen, High recovery membrane desalting of low-salinity brackish water: Integration of accelerated precipitation softening with membrane RO, Journal of Membrane Science, 289 (2007) 123-137.

[14] Ch. Tzotzi, T. Pahiadaki, S.G. Yiantsios, A.J. Karabelas, N. Andritsos, A study of $\mathrm{CaCO}_{3}$ scale formation and inhibition in RO and NF membrane processes, Journal of Membrane Science, 296 (2007) 171-184.

[15] S.P. Chesters, Innovations in the inhibition and cleaning of reverse osmosis membrane scaling and fouling, Desalination, 238 (2009) 22-29.

[16] G. Greenburg, D. Hasson, R. Semiat, Limits of RO recovery imposed by calcium phosphate pecipitation, Desalination, 183 (2005) 273-288.

[17] A. Zach-Maor, R. Semiat, A. Rahardianto, Y. Cohen, S. Wilson, S.R. Gray, Diagnostic analysis of RO desalting treated wastewater, Desalination, 230 (2008) 239-247.

[18] S. F. E. Boerlage, M. D. Kennedy, I. Bremere, G. J. Witkamp, J. P. van der Hoek, J.C. Schippers, The scaling potential of barium sulphate in reverse osmosis systems, Journal of Membrane Science, 197 (2002) 251-268.

[19] G. Braun, W. Hater, C. zum Kolk, C. Dupoiron, T. Harrer, T. Götz, Investigations of silica scaling on reverse osmosis membranes, Desalination, 250 (2010) 982-984.

[20] D.E. George, Prediction of Silica Scale Formation in RO Systems, Desalination, 47 (1983) 161-169.

[21] N. A. Milne, T. O'Reilly, P. Sanciolo, E. Ostarcevic, M. Beighton, K. Taylor, M. Mullett, A. J. Tarquin, S.R. Gray, Chemistry of silica scale mitigation for RO desalination with particular reference to remote operations, Water Research, 65 (2014) 107-133.

[22] R. Semiat, I. Sutzkover, D. Hasson, Scaling of RO membranes from silica supersaturated solutions, Desalination, 157 (2003) 169-191.

[23] R. Sheikholeslami, S. Tan, Effects of water quality on silica fouling of desalination plants, Desalination, 126 (1999) 267-280.

[24] S.D.N. Freeman, R.J. Majerle, Silica fouling revisited, Desalination, 103 (1995) 113-115.

[25] T. Koo, Y.J. Lee, R. Sheikholeslami, Silica fouling and cleaning of reverse osmosis membranes, Desalination, 139 (2001) 43-56.

[26] W. Den, C.-J. Wang, Removal of silica from brackish water by electrocoagulation pretreatment to prevent fouling of reverse osmosis membranes, Separation and Purification Technology, 59 (2008) 318-325.

[27] M. Zaman, G. Birkett, C. Pratt, B. Stuart, S. Pratt, Downstream processing of reverse osmosis brine: Characterisation of potential scaling compounds, Water Research, 80 (2015) 227234.

[28] J. Borden, J. Gilron, D. Hasson, Analysis of RO flux decline due to membrane surface blockage, Desalination, 66 (1987) 257-269.

[29] A. Antony, J. H. Low, S. Gray, A. E. Childress, P. Le-Clech, G. Leslie, Scale formation and control in high pressure membrane water treatment systems: A review, Journal of Membrane Science, 383 (2011) 1-16.

[30] S. Salvador Cob, B. Hofs, C. Maffezzoni, J. Adamus, W.G. Siegers, E.R. Cornelissen, F.E. Genceli Güner, G.J. Witkamp, Silica removal to prevent silica scaling in reverse osmosis membranes, Desalination, 344 (2014) 137-143. 
[31] C.J. Gabelich, A. Rahardianto, C.R. Northrup, T.I. Yun, Y. Cohen, Process evaluation of intermediate chemical demineralization for water recovery enhancement in production-scale brackish water desalting, Desalination, 272 (2011) 36-45.

[32] J. Thompson, A. Rahardianto, H. Gu, M. Uchymiak, A. Bartman, M. Hedrick, D. Lara, J. Cooper, J. Faria, P. D. Christofides, Y. Cohen, Rapid field assessment of RO desalination of brackish agricultural drainage water, Water Research, 47 (2013) 2649-2660.

[33] E.G. Darton, RO plant experiences with high silica waters in the Canary Islands, Desalination, 124 (1999) 33-41.

[34] J. Zhang, H. Zeng, C. Ye, L. Chen, X. Yan, Pilot test of UF pretreatment prior to RO for cooling tower blowdown reuse of power plant, Desalination, 222 (2008) 9-16.

[35] G.B. Alexander, W.M. Heston, R.K. Iler, The Solubility of Amorphous Silica in Water, Journal of Physical Chemistry, 58 (1954) 453-455.

[36] K.R. Applin, The diffusion of dissolved silica in dilute aqeuous solutions, Geochimica et Cosmochimica Acta, 51 (1987) 2147-2151.

[37] R.K. Iler, The Chemistry of Silica: Solubility, Polymerization, Colloid and Surface Properties, and Biochemistry, John Wiley and Sons, Inc., New York, USA, 1979.

[38] O.W. Flörke, H.A. Graetsch, F. Brunk, L. Benda, S. Paschen, H.E. Bergna, W.O. Roberts, W.A. Welsh, C. Libanati, M. Ettlinger, D. Kerner, M. Maier, W. Meon, R. Schmoll, H. Gies, D. Schiffmann, Silica, Ullmann's Encyclopedia of Industrial Chemistry, (2008).

[39] S. Musić, N. Filipović-Vinceković, L. Sekovanić, Precipitation of Amorphous $\mathrm{SiO}_{2}$ Particles and Their Properties, Brazilian Journal of Chemical Engineering, 28 (2011) 89-94.

[40] S.K. Wason, Cosmetic properties and structure of fine-particle synthetic precipitated silicas, Journal of the Society of Cosmetic Chemists, 29 (1978) 497-521.

[41] T. Jesionowski, Characterization of silicas precipitated from solution of sodium metasilicate and hydrochloric acid in emulsion medium, Powder Technology, 127 (2002) 56-65.

[42] A.D. Bishop Jr., J.L. Bear, The thermodynamics and kinetics of the polymerization of silicic acid in dilute and aqueous solution, Thermochim. Acta 3(1972) 399-409.

[43] E. A. Gorrepati, P. Wongthahan, S. Raha, H.S. Fogler, Silica Precipitation in Acidic Solutions: Mechanism, pH Effect, and Salt Effect, Langmuir, 26 (2010) 10467-10474.

[44] A.C. Makrides, M. Turner, J. Slaughter, Condensation of silica from supersaturated silicic acid solutions, J. Colloid Interf. Sci., 73 (1980) 345-367.

[45] R.Y. Ning, A. Tarquin, J.E. Balliew, Seawater RO treatment of RO concentrate to extreme silica concentrations, Desalin. Water Treat, 22 (2010) 286-291.

[46] Z. Amjad, R. Zuhl, Solution Chemistry Impact on Silica Polymerization by Inhibitors, in: Mineral Scales in Biological and Industrial Systems, CRC Press/Taylor \& Francis Group, 2013.

[47] W. Marshall, Amorphous silica solubilities--I. Behavior in aqeuous sodium nitrate solutions; 25-300 ${ }^{\circ} \mathrm{C}, 0-6$ molal, Geochimica et Cosmochimica Acta, 44 (1980) 907-913.

[48] R.K. Iler, The Colloid Chemistry of Silica and Silicates, Cornell Univ. Press, Ithaca, NY, 1955.

[49] I. Gunnarsson, S. Arnórsson, Amorphous silica solubility and the thermodynamic properties of $\mathrm{H}_{4} \mathrm{SiO}_{4}$ in the range of $0^{\circ}$ to $350^{\circ} \mathrm{C}$ at $\mathrm{P}_{\text {sat }}$, Geochimica et Cosmochimica Acta, 64 (2000) 2295-2307.

[50] J.S. Gill, Inhibition of silica-silicate deposit in industrial waters, Colloid Surf A: Physiochem Eng Aspects, 74 (1994) 101-106.

[51] E. Neofotistou, K.D. Demadis, Use of antiscalants for mitigation of silica $\left(\mathrm{SiO}_{2}\right)$ fouling and deposition: fundamentals and applications in desalination systems, Desalination, 167 (2004) 257272. 
[52] R. Semiat, I. Sutzkover, D. Hasson, Characterization of the effectiveness of silica antiscalants, Desalination, 159 (2003) 11-19.

[53] Baoxia Mi, M. Elimelech, Silica scaling and scaling reversibility in forward osmosis, Desalination, 312 (2013) 75-81.

[54] B. Durham, A. Walton, Membrane pretreatment of reverse osmosis: long-term experience on difficult waters, Desalination, 122 (1999) 157-170.

[55] R. Semiat, I. Sutzkover, D. Hasson, Technique for evaluating silica scaling and its inhibition in RO desalting, Desalination, 140 (2001) 181-193.

[56] A.H. Taheri, L.N. Sim, T.H. Chong, W.B. Krantz, A.G. Fane, Prediction of reverse osmosis fouling using the feed fouling monitor and salt tracer response technique, Journal of Membrane Science, 475 (2015) 433-444.

[57] T.H. Chong, F.S. Wong, A.G. Fane, Fouling in reverse osmosis: Detection by non-invasive techniques, Desalination, 204 (2007) 148-154.

[58] S.T.V. Sim, W.B. Krantz, T.H. Chong, A.G. Fane, Online monitor for the reverse osmosis spiral wound module -- Development of the canary cell, Desalination, 368 (2015) 48-59.

[59] A.H. Taheri, S.T.V. Sim, L.N. Sim, T.H. Chong, W.B. Krantz, A.G. Fane, Development of a new technique to predict reverse osmosis fouling, Journal of Membrane Science, 448 (2013) $12-22$.

[60] A.P. Mairal, A.R. Greenberg, W.B. Krantz, Investigation of membrane fouling and cleaning using ultrasonic time-domain reflectometry, Desalination, 130 (2000) 45-60.

[61] A.P. Mairal, A.R. Greenberg, W.B. Krantz, L.J. Bond, Real-time measurement of inorganic fouling of RO desalination membranes using ultrasonic time-domain reflectometry, Journal of Membrane Science, 159 (1999) 185-196.

[62] L.N. Sim, Z.J. Wang, J. Gu, H.G.L. Coster, A.G. Fane, Detection of reverse osmosis membrane fouling with silica, bovine serum albumin and their mixture using in-situ electrical impedance spectroscopy, Journal of Membrane Science, 443 (2013) 45-53.

[63] J.M. Kavanagh, S. Hussain, T.C. Chilcott, H.G.L. Coster, Fouling of reverse osmosis membranes using electrical impedance spectroscopy: Measurements and simulations, Desalination, 236 (2009) 187-193.

[64] Z. Hu, A. Antony, G. Leslie, P. Le-Clech, Real-time monitoring of scale formation in reverse osmosis using electrical impedance spectroscopy, Journal of Membrane Science, 453 (2014) 320-327.

[65] H. Gu, A. R. Bartman, M. Uchymiak, P. D. Christofides, Y. Cohen, Self-adaptive feed flow reversal operation of reverse osmosis desalination, Desalination, 308 (2013) 63-72.

[66] A. R. Bartman, E. Lyster, R. Rallo, P.D. Christofides, Y. Cohen, Mineral scale monitoring for reverse osmosis desalination via real-time membrane surface image analysis, Desalination, 273 (2011) 64-71.

[67] Y. Cohen, M. Uchymiak, U.S. Patent 7,910,004, Method and System for Monitoring Reverse Osmosis Membranes, in, March 22, 2011.

[68] J. Thompson, N. Lin, E. Lyster, R. Arbel, T. Knoell, J. Gilron, Y. Cohen, RO membrane mineral scaling in the presence of a biofilm, Journal of Membrane Science, 415-416 (2012) 181191.

[69] E. Lyster, J. Au, R. Rallo, F. Giralt, Y. Cohen, Coupled 3-D hydrodynamics and mass transfer analysis of mineral scaling-induced flux decline in a laboratory plate-and-frame reverse osmosis membrane module, Journal of Membrane Science, 339 (2009) 39-48. 
[70] E. Lyster, Y. Cohen, Numerical study of concentration polarization in a rectangular reverse osmosis membrane channel: Permeate flux variation and hydrodynamic end effects, Journal of Membrane Science, 303 (2007) 140-153.

[71] D. Lisitsin, D. Hasson, R. Semiat, Critical flux detection in a silica scaling RO system, Desalination, 186 (2005) 311-318.

[72] R.Y. Ning, Discussion of silica speciation, fouling, control and maximum reduction, Desalination, 151 (2002) 67-73.

[73] S.H. Chan, A review on solubility and polymerization of silica, Geothermics, 18 (1989) 4956.

[74] R. Sheikholeslami, I.S. Al-Mutaz, T. Koo, A. Young, Pretreatment and the effect of cations and anions on prevention of silica fouling, Desalination, 139 (2001) 83-95.

[75] P. Sahachaiyunta, T. Koo, R. Sheikholeslami, Effect of several inorganic species on silica fouling in RO membranes, Desalination, 144 (2002) 373-378.

[76] OLI Systems Inc., OLI Studio 9.2, in, Morris Plains, NJ.

[77] A.L. Zydney, Stagnant film model for concentration polarization in membrane systems, Journal of Membrane Science, 130 (1997) 275-281.

[78] N. Otsu, A Threshold Selection Method from Gray-Level Histograms, IEEE Transactions on Systems, Man, and Cybernetics, SMC-9 (1979) 62-66.

[79] A. S. Krishna, G. S. Rao, M. Sravya, Contrast Enhancement Techniques Using Histogram Equalization on Color Images with Poor Lighting, International Journal of Computer Science, Engineering and Applications, 3 (2013).

[80] R.C. Gonzalez, R.E. Woods, Digital Image Processing, Third ed., 2008.

[81] H.P. Rothbaum, A.G. Rohde, Kinetics of Silica Polymerization and Deposition from Dilute Solutions between 5 and $180^{\circ} \mathrm{C}$, Journal of Colloid and Interface Science, 71 (1979) 533-559.

[82] Hydranautics, Foulants and Cleaning Procedures for composite polyamide RO Membrane Elements, in: Technical Service Bulletin 107.24, 2014.

[83] O. Söhnel, J. Garside, Precipitation, Butterworth-Heinemann Ltd, 1992.

[84] E. Lyster, M-m. Kim, J. Au, Y. Cohen, A method for evaluating antiscalant retardation of crystal nucleation and growth on RO membranes, Journal of Membrane Science, 364 (2010) 122-131.

[85] M. Kley, A. Kempter, V. Boyko, K. Huber, Mechanistic Studies of Silica Polymerization from Supersaturated Aqueous Solutions by Means of Time-Resolved Light Scattering, Langmuir, 30 (2014) 12664-12674.

[86] W.M. Haynes, CRC Handbook of Chemistry and Physics, 92nd ed., CRC Press, Boca Raton, FL, 2011. 